\title{
Unfamiliar and Unknown Dionysiac Rituals
}

\author{
Boys and Girls in the Realm of Dionysos
}

Amongst the cups of around 490 BC one by the Triptolemos Painter stands out. It refers explicitly to some Dionysiac ritual. ${ }^{1}$ In the unusual tondo image Dionysos is greeted with a libation, but not by a woman or a satyr, but by a boy: either Dionysos' son Oinopion or a boy who, in some ritual context, doubles as Oinopion (Figure 67). ${ }^{2}$ This motif is already attested in the 6th century in the work of Exekias and the Amasis Painter and may, even at this early stage, refer to a festival during which Athenian ephebes had a ritual encounter with Dionysos. ${ }^{3}$ The opinion, still current, that in vase imagery the mythical world and that of ordinary human life can be distinguished from each other, should

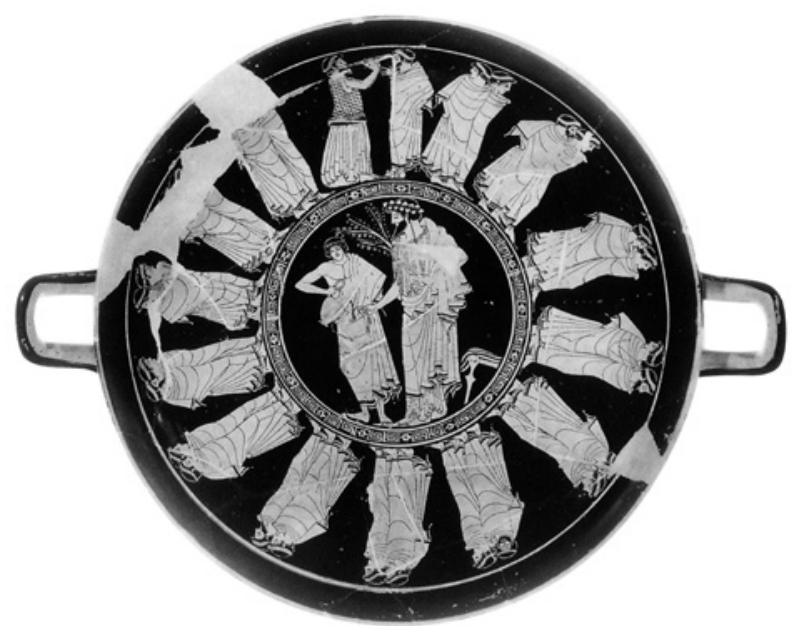

FIGURE 67 Cup, Triptolemos Painter, Paris, Louvre G 138, view of the inside (Knauer 1996, 222, pl. 1).

1 For the Triptolemos Painter, see above Chapter 3 , note 89.

2 Louvre G 138: Addenda 223 (365.61); вA 203853; Knauer 1996, 221-239. The image of another cup by the Triptolemos Painter has been said to refer to the Dionysiac festival known as the Oschophoria (Knauer 1996, 239-246). This interpretation, however, remains uncertain because of the extremely fragmentary condition of the cup.

3 Isler-Kerényi 2007, 140-142, figs 74 and 75. 
really be considered obsolete. On the Triptolemos Painter's cup, thirty-four men and boys solemnly move in pairs towards the right around the medallion and in one of the outside images. They are wrapped in their himatia and led by an aulos player. ${ }^{4}$ Nineteen boys have their name indicated; some of them are known from kalós inscriptions on other vases of the same period. The other outside image shows a bearded man and four youths, who seem to be looking at the procession. It is obvious that here-if ever there was an example in vase painting - we have the depiction of a particular procession. Elfriede Knauer has convincingly argued that this procession took place on the third day of the Dionsysiac festival of the Apatouria. On this day, called Koureotis, the sixteenyear olds came out, accompanied by their fathers, to celebrate that they had reached the status of ephebe, after the ritual cutting of their long hair. ${ }^{5}$

A cup that can be dated around the middle of the century from the circle of the Penthesilea Painter deserves to be discussed in some detail, even though it is artistically much more modest (Figure 68). ${ }^{6}$ The interior shows an anonymous woman performing a libation in front of a seated Dionysos who holds a kantharos in his right hand. On one of the outside images we see a line of eight girls and women, who stride solemnly towards the right holding hands. Is this a procession, a quiet dance, or both? ${ }^{7}$ On the other side two scenes are juxtaposed. The right hand scene shows a girl, characterized as such by her uncovered long hair, with a torch in each hand in front of an altar. ${ }^{8}$ To her left an older woman holds a skyphos over the altar, possibly for a libation. Next there are two women interacting by way of a gesture that is, so far, unclear. The left hand scene also has four figures. On the right stands a young man, dressed in a himation, who seems to be holding an aulos in each of his lifted hands. In front of him, also looking towards the left, stands a little girl, wrapped in a himation. She watches a young man, who plays the aulos in a most lively manner. He is naked apart from a narrow chlamys over his left shoulder. The last figure in this scene is a bearded komast, seen en face, who swings his gnarled stick and chlamys as he dances along.

4 Pairs of men (in this case in a pedagogic-erotic sphere) also occur in the tondo image of a cup by Douris, Louvre G 121: Addenda 238 (434.78); BA 205123; Buitron-Oliver 1995, 26 and 8o, no. 125 , pls. $76-77$.

Knauer 1996, $233 \mathrm{f}$.

6 Florence 3950: ARV 914.142; BA 211080; Paleothodoros 2010, 247-249, fig. 17.8.

7 Compare the dance of young girls on the eponymous calyx krater by the Villa Giulia Painter, Rome, Villa Giulia 909: Addenda 270 (618.1); BA 207149. In this case, however, only the aulos could be an indication that this is a Dionysiac ritual.

8 It is, therefore, improbable that this is one of the gerairai at the Anthesteria as Paleothodoros 2010, 248 supposes. 


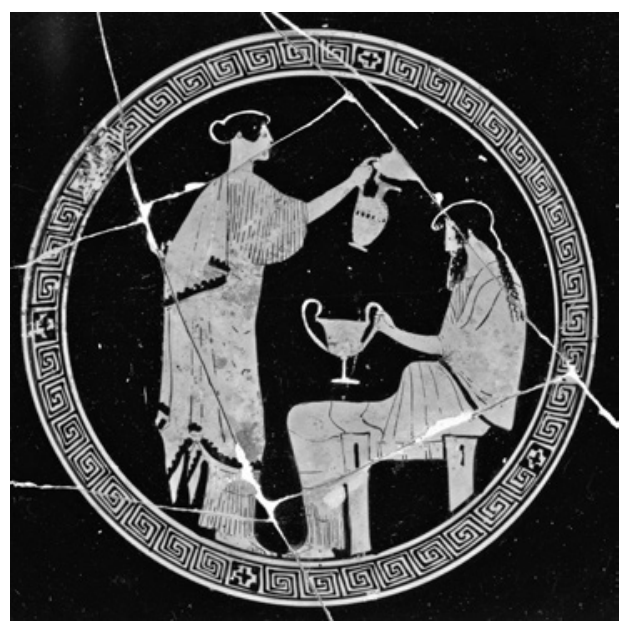

$a$

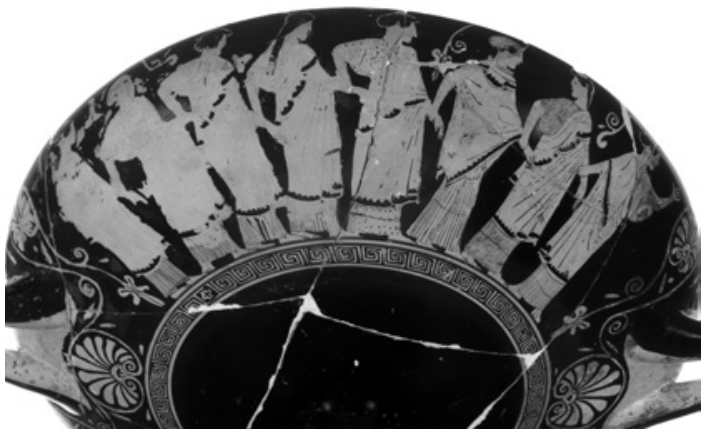

$b$

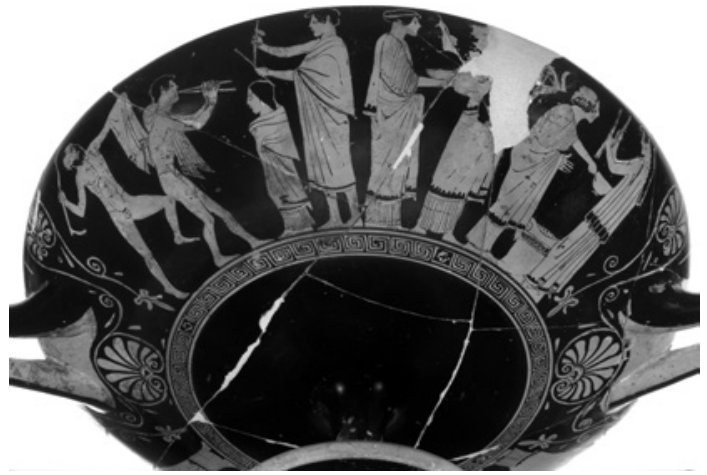

$c$

FIGURE 68 Cup, Florence 3950 (photographs Museo Archeologico Etrusco).

a. tondo image.

b. outside image A: dancing women.

c. outside image B: music lesson and sacrificial scene. 
How should all this be interpreted? Surely these scenes must show some ritual occasion of a Dionysiac nature and in the female sphere, as the interior image of the cup indicates - a ritual in which women of various ages participate. It is rather surprising to find this little girl among the komasts. Is she training for a career as a symposium musician? ${ }^{9}$ The only parallel piece, though of far better workmanship, is the cup by the Triptolemos Painter discussed above, with Dionysos and perhaps Oinopion on the inside, and the processions of men and boys. One could imagine that the cup with the little girl presents the female counterpart of the ritual depicted by the Triptolemos Painter.

\section{A Domestic Dionysiac Ritual}

In the decades after $470 \mathrm{BC}$ a rather striking Dionysiac motif became popular at the Kerameikos. It shows a ritual performed by women around a remarkable idol of the god. The motif is already used between 490 and 480 on a series of late black figure lekythoi and on the Berlin cup by Makron discussed earlier (Figure 69). ${ }^{10}$ From about 470 the motif is found exclusively on the vase type we now call stamnos. Let us, before investigating the imagery, have a closer look at the carrier.11

The vases we designate as stamnoi belong to the new shapes introduced by potters at the Kerameikos around 530 BC. As was the case with several other shapes, this novelty was intended for the Etruscan market and inspired by Etruscan examples. In Etruscan territory, its antecedents were used as burial urns as early as the 7 th century. ${ }^{12}$ Stamnoi were made in Athens for only slightly more than a century. Their disappearance from the repertoire coincides-but not coincidentally - with a decrease in demand on the Etruscan export market. These were always exclusive and probably expensive items. This is not only clear from their sophisticated and variegated forms, but also from the fact that their decoration shows greater refinement compared to that of the more common vase types, such as column kraters and small neck-amphorae. ${ }^{13}$ Apart from the ubiquitous anonymous women, men and youths, stamnoi frequently

Compare, for instance, the fine interior image of a cup in Paris, Louvre G 135: Addenda 221 (355.45); BA 203728 (Colmar Painter) and the komos accompanied by a young female flute player on the column krater Cefalù 1 (Painter of the Florence Centauromachy): Tullio 1996, 142 f., fig. $1-2$.

10 Berlin F 229o: Addenda 244 (462.48); BA 204730. See above Chapter 3, note 114.

11 What follows is discussed in greater detail in Isler-Kerényi 2009b.

12 Isler-Kerényi 1976, 41-45; Sisto 2006, 154.

13 Philippaki 1967 passim, especially $15^{-152 .}$ 


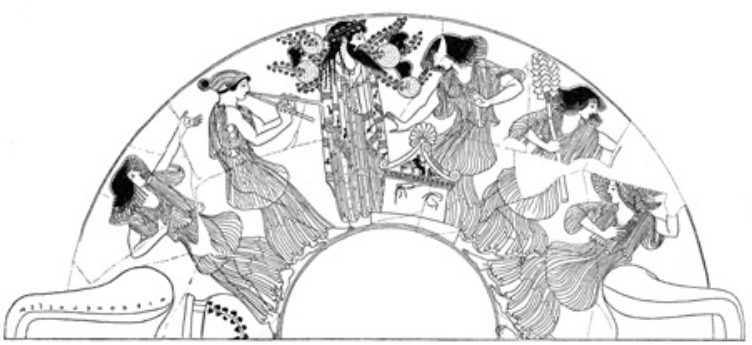

$a$

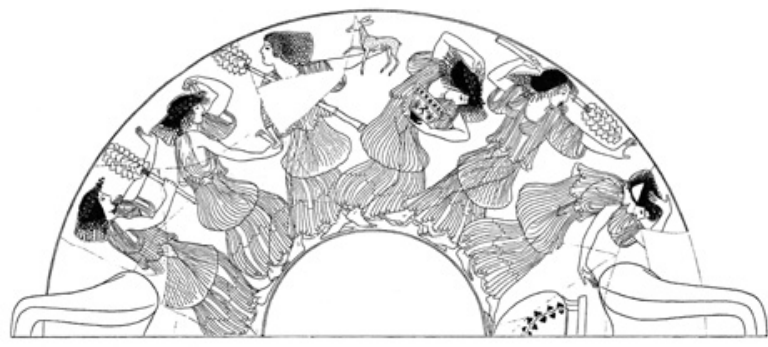

$b$

FIGURE 69 Cup, Makron, Berlin F 2290 (Frickenhaus 1912, 6 and 7).

a. outside image A: Dionysos idol.

b. outside image B: dancing women.

show figures from the Dionysiac realm: Dionysos himself, women dancing and performing rituals, satyrs. These figures (and depictions of komos and symposium) are even more numerous than mythological characters, which are also frequently depicted. Relatively common is the motif of the amorous pursuit or abduction by a god, which, as is well known, served as a metaphor for a sudden death. I should add, though, that the pursuit of a woman by a male figure (Thetis by Peleus, Oreithyia by Boreas, Helena by Theseus, Aithra or Amymone by Poseidon, Aegina by Zeus) is much more frequent than its opposite (for instance Kephalos or Tithonos by Eos). Also quite common is that other metaphor of death: the arming and farewell of a warrior. It befits the exclusivity of the stamnos shape that, more than other shapes, it carries unique designs: Herakles wrestling with Acheloos (by Oltos); Orestes killing Aigisthos (by the Berlin Painter); Danae and her little son Perseus (by the Eucharides Painter); the assassination of the tyrants (by Syriskos), and so on. ${ }^{14}$

14 London E 437: Addenda 163 (54.5); BA 200437; Boston 91.227a and 91.226b: Addenda 195 (208.151); BA 201970; St. Petersburg 1549 (B 642): Addenda 199 (228.30); BA 202231; Würzburg 515: Addenda 204 (256.5); BA 202924. 
What purpose did the stamnos serve? With its small horizontal handles it asks for circumspection when lifting it—as is, incidentally, confirmed by some images..$^{15}$ For this reason, and because of its comparatively narrow opening, the stamnos seems less useful for mixing wine at the symposium than the krater, even though it may occasionally have been used for just this purpose. The narrow neck was originally closed by a lid: this has been preserved with some of the surviving stamnoi. ${ }^{16}$ The provenance of most stamnoi is unfortunately unknown and thus we have but little clues as to their use. There are, however, some indications. A grave in Eleusis contained one of the very few stamnoi with an indisputable Greek provenance. ${ }^{17}$ That an Attic stamnos could be used as an urn is proven by an example (preserved with its lid) from a grave in Capua, legitimately excavated, and still containing the cremation. ${ }^{18}$

The other usage is ritual. This is not only clear from the stamnos from Eleusis just mentioned, which featured an Eleusinian procession; it can also be concluded from the special motif that is our main interest here. The motif occurs on 29 stamnoi and fragments of stamnoi, eight of them with only minor variations on a single design. In the center of the symmetrical composition we see a construction that obviously represents the god Dionysos: it consists of a pillar on which are fastened a mask, several branches, two round objects at shoulder height, and a garment that almost reaches to the ground. The interpretation of the round objects has been discussed at length: cakes and libation dishes have, for instance, been proposed. ${ }^{19}$ Cultic bronze cymbals are, however, more likely — these have been excavated at several sanctuaries across the Greek world. ${ }^{20}$ The identification as cymbals is also supported by the fact that they are fastened at shoulder height. ${ }^{21}$ In front of the idol there is a low table, like the table in symposium scenes, on which are placed two stamnoi. To either side a woman is, quietly and intently, ladling wine from the stamnoi with ladles and drinking vessels. The reverse sides of these stamnoi are also quite uniform:

\footnotetext{
15 See for instance Frontisi-Ducroux 1991, 98, fig. 38, and 157, fig. 94.

16 Isler-Kerényi 2oogb, 76, note 10.

17 Eleusis 636: Addenda 321 (1052.23); вA 213653 (no image).

18 Johannowsky 1983, 201 f., pls. 39-40; Hamilton 1992, 136 with note 50. This probably also holds true for an example from Gela: Isler-Kerényi 2009b, 76, note 7. See in addition De Cesare 2007, 12.

19 Frontisi-Ducroux 1991, 72; Halm-Tisserant 1991, $81 \mathrm{f}$.

20 Bellia 2012, 3-14, especially 6 , fig. 7.

21 Personal communication from Angela Bellia, August 7th 2012: "L'uso di appendere al collo doveva essere funzionale nel corso dei riti e delle processioni: non si correva il rischio di perderli ed erano sempre 'pronti' per essere suonati."
} 

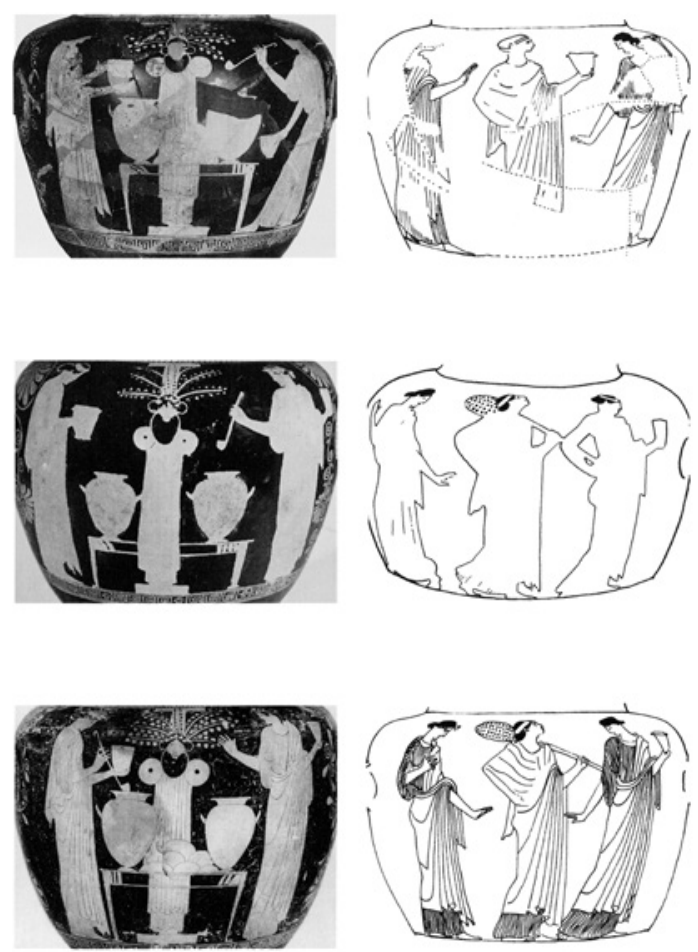

FIGURE 70 Stamnoi, Villa Giulia Painter (Frontisi-Ducroux 1991, 73).

they show three of four women who, in a measured dance, move towards the right, carrying thyrsoi, drinking vessels and sometimes an aulos or a parasol.

Because of their uniformity these images have aroused great interest among students of ancient religion ever since their first publication in 1912 (Figure 70). ${ }^{22}$ This turned into a long-running debate on the question which of the known Dionysiac festivals these images referred to. Since the fundamental re-appraisal of the evidence by Frontisi-Ducroux, however, the problem has been solved. ${ }^{23}$ These images should not be seen as depicting a certain moment in an actual ritual, but rather as an evocation. They do not refer to one of the official festivals of Athens, but, as we will see, to domestic rituals in honor of the god, for which we have independent evidence. ${ }^{24}$ Beazley has shown that of the 29 stamnoi with this motif, thirteen have been decorated by the Villa

\footnotetext{
22 Frickenhaus 1912.

23 Frontisi-Ducroux 1991, 41-63.

24 Compare Paul-Zinserling 1994, 19 f.; Schlesier 1997, 656 (with some question marks). Compare also Seaford 2006, 46 and 71, although it remains an open question where the
} 
Giulia Painter, including the eight nearly identical ones. ${ }^{25}$ This painter must have been the inventor of this symmetrical design that was aesthetically pleasing and became popular.

As stated above, however, the motif itself was already present in the repertoire of Athenian vase painters for over a generation. It was also adopted by other painters, more or less related to the Villa Giulia Painter, and they came up with their own versions: the little table may be absent, one of the women may be seated, a sacrificial basket may be added to the composition (Figure 71). ${ }^{26}$ These variations show that the execution of the ritual was not bound to rigid rules, as one might expect of a ritual in a private, domestic setting. In every instance, however, the ceremony is performed by women around a temporary idol of Dionysos (although men were definitely not completely excluded). ${ }^{27}$ The mask, or rather the portrait of the god in frontal view, evokes, together with the empty garment, the absent god-his gaze, however, is all the more effective as it is not directed towards the women in the image, but towards the female viewer who identifies with them. ${ }^{28}$ Obviously, one of the ritual acts was the ladling of small amounts of some liquid from the stamnoi. The kantharos, that is often present in addition to the skyphos, the drinking vessel usually associated with women, implies that the liquid is unmixed wine. ${ }^{29}$ With the wine the women ingest the god: their, literally, enthusiast state is reflected in the Bacchic dance on the reverse side of the vase. ${ }^{30}$

Individual ritual acts always refer to the deeper meaning of the ritual itself. In order to identify that meaning we should depart from what we can conclude from provenance and function. On the one hand, stamnoi could contain the pure wine that was equated with Dionysos. On the other, they could function as urns to receive the ashes of the dead. What could be the common denominator of pure wine and ashes? Both are the result of a metamorphosis, a Dionysiac event: the grapes change into wine, the dead into ashes. This leads almost automatically to the understanding that, just as the crushed, 'killed', grape turns into wine, a new and wonderfully effective substance, the enthusiast human will after death enter a new, as yet unimagined, existence.

\footnotetext{
"secret cult" (as opposed to the official and public one) took place; Schöne-Denkinger 2008, 51; Schwarzmaier 2008, 86-89.

25 Concerning the Villa Giulia Painter, see above Chapter 5, p. 90.

26 Isler-Kerényi 2009b, 78 and 88 f., figs $1-6$.

27 Frontisi-Ducroux 1991, $146 \mathrm{f}$. with figs 85 and $170 \mathrm{f}$. (compare however Osborne 1997, 207).

28 Accordingly Osborne 1997, 210.

29 Frontisi-Ducroux 1991, 80, fig. 18; 152, fig. 89; 155, figs 90 and 91.
}

$30 \quad$ Osborne 1997, 208. 

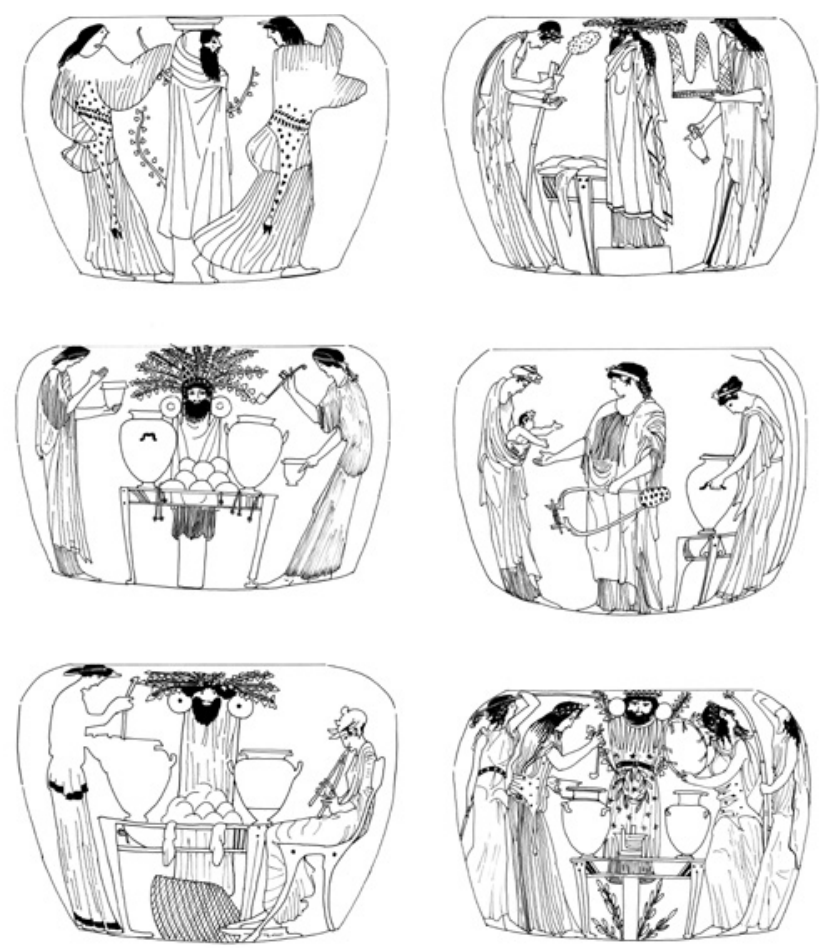

FIGURE 71 Stamnoi, various painters (Isler-Kerényi 20ogb, 88f., figs 1-6).

Our perusal of the Dionysiac repertoire on vases of the second quarter of the century has shown a ritualizing of the imagery, which points to a growing sacralization of the public mood around $45^{\circ}$ вС. It is within that context that we should situate the stamnoi evocating Bacchic ongoings in the private sphere. It is certain that such ongoings took place in Athens. ${ }^{31}$ Nevertheless, considering the provenance of the Athenian stamnoi, especially the group discussed above, we should ask ourselves for what kind of buyers these images were intended. It can be calculated that of every twenty stamnoi produced at the Kerameikos, at most just a single one remained in Greece: the others were exported to Italy. ${ }^{32}$ All vases decorated with the ritual around the Dionysos idol of which the provenance is known, have either been found in Etruria, especially Vulci, or in the north of Campania, culturally much influenced by Etruria. That the stamnoi by the Villa Giulia Painter and his colleagues were so

\footnotetext{
$31 \quad$ See above note 27.

32 Isler-Kerényi 1994, 48.
} 
much in demand in Etruria cannot only be explained from the huge popularity of Dionysos since archaic times and the adoption of the symposium. Ancient cultural boundaries were much more permeable than we can imagine in our own times, so much characterized by national feeling. ${ }^{33}$ And there are more direct indications: we have several Etruscan graffiti on vases imported from Athens around 470 BC that point to the existence, also in Vulci, of a cult of Fufluns Pachies, i.e. Dionysos Bakchos. ${ }^{34}$ Thus, our stamnoi may have been used outside Athens in a way that matches their decoration. ${ }^{35}$

A series of stamnoi decorated by younger associates of the Villa Giulia Painter cannot be seen apart from the stamnoi with the Dionyos idol. These show a female thiasos, without any characteristic accoutrements, but in an obviously ritual setting. ${ }^{36}$ Particularly remarkable are the stamnoi by the Phiale Painter, who was active between $45^{\circ}$ and $425 \mathrm{BC}$. He was a pupil of the Achilles Painter and one of the leading artists of his time. ${ }^{37}$ Like his teacher, he mostly decorated small red-figure neck-amphorae and lekythoi, and a series of whiteground vases. In his work, too, Dionysiac imagery is not pre-eminent, but it has some interesting individual representations. His white-ground krater with the handing over of the infant Dionysos has already been discussed. ${ }^{38}$ Dionysos rarely appears on the small neck-amphorae. More common are various scenes with satyrs and maenads who look strikingly human. ${ }^{39}$ Komasts probably only appear on some of his rare cups. ${ }^{40}$ We repeatedly encounter satyrs wearing himatia, as we did in the oeuvre of the Geras Painter-satyrs presented as citizens. ${ }^{41}$ They walk together, stand opposite two Dionysiac women, or are

33 Isler-Kerényi 1999a.

34 Isler-Kerényi 2003, 45 with notes 35 and 36.

35 Similarly La Genière 2013, $33 \mathrm{f}$.

36 ARV 628 f. 7-12 (Chicago Painter); Addenda 272 (633.8); BA 207343 and ARV 633.9; BA 207344 (no image, Methyse Painter). Frontisi-Ducroux 1991, 100, note 72; Osborne 1997, 206. Compare in addition a stamnos by Syriskos, datable between 480 and $470 \mathrm{BC}$, in a private collection in Germany: Wehgartner 1997, 116-119 (the reference to the Lenaia is no longer tenable).

37 Oakley 1990, 6.

38 Vatican 16586 (559): see above Chapter 5 , note 76.

39 Oakley $1990,36$.

40 Leipzig T 3376: ARV 1023.149; BA 214332; Adria B 604: ARV 1024.152; BA 214335; Adria B 626: ARV 1024. 153; BA 214336.

See above Chapter 3 , note 60 . 


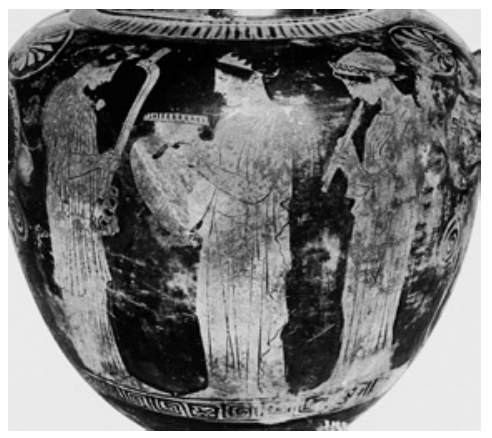

$a$

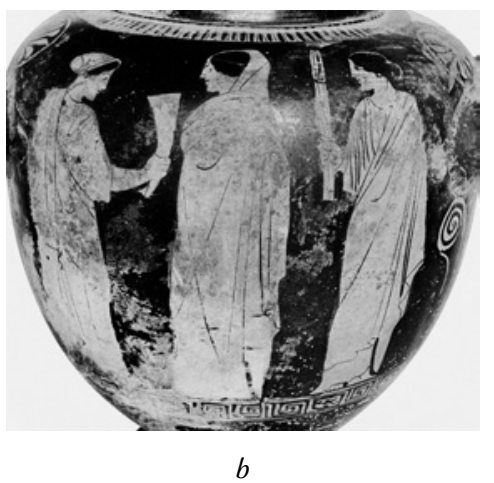

FIgure 72 Stamnos, Phiale Painter, Museo Nazionale Archeologico, Naples 164332, (Oakley 199o, pl. 64). Su concessione del Ministero dei Beni e delle Attività Culturali e del Turismo-Soprintendenza per i Beni Archeologici di Napoli.

a. side $A$.

b. side $B$.

engaged in conversation with one of these. ${ }^{42}$ Are these satyrs dressed up as citizens, or citizens identifying with satyrs? ${ }^{43}$

On the first stamnos, to be dated at the beginning of his career, around $45^{0-}$ $445 \mathrm{BC}$, each side is decorated with women engaged in ritual acts (Figure 72) ${ }^{44}$ In the center of the main side a woman wearing a diadem appears to carry

42 Naples Stg 240: ARV 1015.22; BA 214199 (Nolan amphora); London E 384: ARV 1017.48; BA 214226 (pelike); Louvre G 422: Addenda 315 (1019.77); BA 214255 (bell krater).

43 See above Introduction note 13 and 15. In addition Paul-Zinserling 1994, 46 f. As for the so-called "satyre bourgeois": Lissarrague 2013, 204-206.

44 Naples 164332: ARV 1019.83; BA 214263 (no image); Oakley 1990, no. 83, pl. 64. The stringed instrument is a barbitos. 

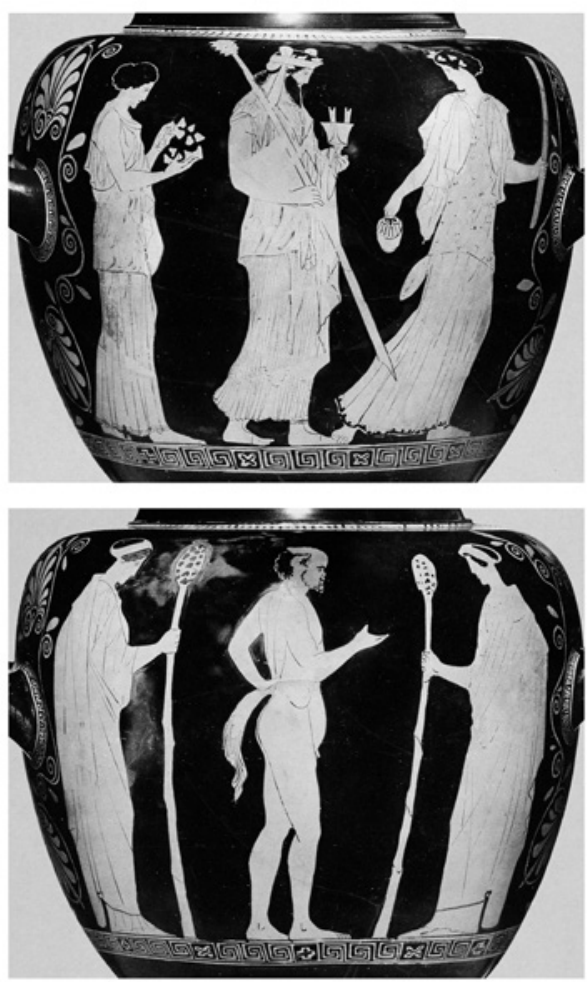

FIgURE 73 Stamnos, Phiale Painter, art trade, sides A and B (Oakley 199o, pl. 67).

a large stamnos to a woman holding a barbitos on the left, assisted by the music of a female aulos player on her right. On the reverse, a woman completely wrapped in a himation stands between a female torch bearer (right) and a woman presenting a drinking horn (left). The presence of the stamnos makes it probable that this, too, is a representation of the ritual at the temporary Dionysos idol. The imagery decorating a stamnos of about the same period is comparable. ${ }^{45}$ The stamnos is absent, but the attributes of the three women on either side include three thyrsoi, a kantharos and a drinking horn, a barbitos, and two torches. A procession with Dionysos himself between two women is depicted on the third of these stamnoi (Figure 73). ${ }^{46}$ The god is bearded, wears soft shoes with his chiton, and has thyrsos and kantharos in his hands. The woman who walks on his right appears to be showing the way with her torch. In her left hand she has an oinochoe to welcome the god and over her

45 Palermo 2183: ARV 1019.84; BA 214264; Oakley 1990, 36 and 8o, no. 84, pls. 65 A-B and 66.

46 Art trade: BA 31374 (no image); Oakley 1990, 36 and 8o, no. 8bis, pl. 67. 
chiton she wears an animal skin. The woman to the left of the god holds an ivy wreath and also has an animal skin over her garment. On the reverse a satyr is seen conversing with two women carrying thyrsoi. Such images are in essence no different from the Dionysos imagery on other vase types, where we also encounter Dionysos himself in the thiasos in the company of a young satyr, as on the bell kraters by the Methyse Painter and Christie Painter to be discussed below. ${ }^{47}$

Amongst the stamnoi decorated with the ritual around the idol, the one by the Phiale Painter is particularly original and informative (Figure 74$).^{48}$ It can be seen as a link between the stamnoi with women engaged in ritual, the images of child satyrs to be discussed in a moment, and the representations of the handing over of the child Dionysos explored already. ${ }^{49}$ The main side shows three women with ivy wreaths. The one on the right is in the act of carefully placing a stamnos, which she holds by its handles, on a small table. A pillar indicates that this scene takes place indoors. The statuesque woman in the center, the only one to wear her hair loose, turns to the left, towards the child that her companion on the left extricates from the folds of the chiton gathered around her waist and hands to her. In her left hand, and therefore prominently in the center of the image she holds a barbitos. As one of the stamnoi of the series discussed above confirms, a stringed instrument belonged to the requi-

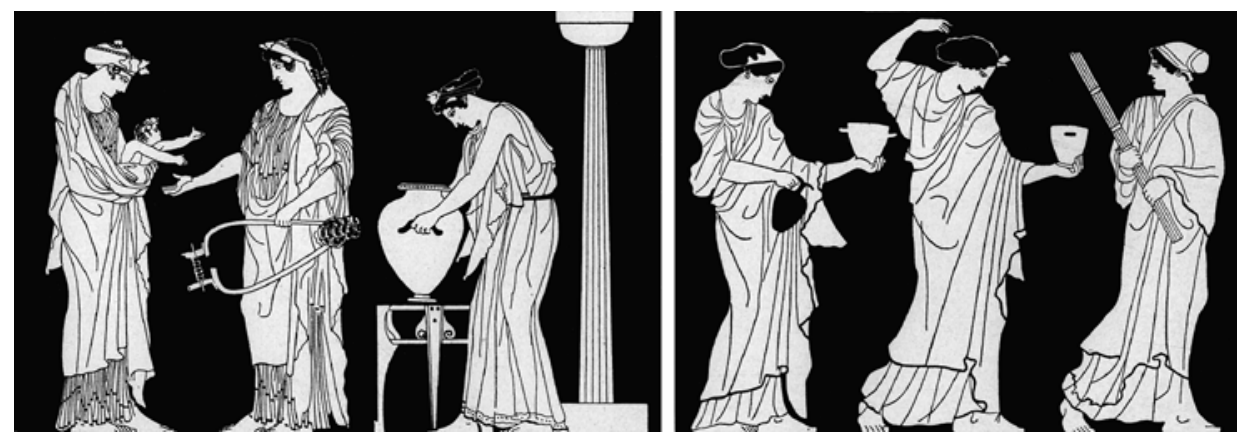

FIGU Re 74 Stamnos, Phiale Painter, Warsaw, National Museum 142465, sides A and B (Frickenhaus 1912, 13).

48 Warsaw 142465: Addenda 315 (1019.82); BA 214262; Oakley 1991, 36 and 80, no. 82, pls. 62A, 63A-B; Frontisi-Ducroux 1991, 156-158, figs 94 and 95. Concerning his calyx krater with the handing over of the child Dionysos, see above Chapter 5 , note 76. 
sites of the ceremony, together with the aulos. ${ }^{50}$ Also it symbolizes music and, in this way, enculturation. The truly remarkable thing is that the child is not the infant Dionysos, nor a human baby, but a newborn satyr. ${ }^{51}$ On the other side three women move towards the right. On the left an apparently somewhat younger woman with a skyphos and an oinochoe, in the center a woman with her hair done up dances with a skyphos in her left hand, and on the right a woman with her hair in a coif indicates the way with her torch. It seems as if the stamnos not only refers to a ritual, but also to three successive stages in a woman's life.

A comparison with the handing over of the child Dionysos is illuminating. Dionysos is usually entrusted to the nymphs of the uncultivated wild or to the old satyr, the father and educator known from satyr plays. As stated above, the god, though a son of Zeus and guarantor of Zeus' order, had to go through a phase of taming and education in nature. The mother of the newborn satyr, however, apparently hands him to a Muse, in some interior where a stamnos with the 'newborn' wine has just been brought in..$^{52}$ A satyr baby will have a satyr father, and will have been conceived in a state of Dionysiac suspension, possibly out of wedlock. ${ }^{53}$ The image therefore suggests that the purpose of domestic Dionysiac rituals of this kind may have been to integrate even these children into the family and, in this way, into the polis. ${ }^{54}$

\section{Dionysos' Chair}

In the second quarter of the $5^{\text {th }}$ century chairs that may have played some ritual role appear in a Dionysiac context, even though they figure less prominently than torches and altars. It seems therefore worthwhile to study the meaning of this requisite, which figures in three different scene types. ${ }^{55}$

$5^{0} \quad$ For the stringed instrument see Frontisi-Ducroux 1991, 87, fig. 21; Osborne 1997, 205.

$5^{1}$ A detail not noticed by Osborne 1997, 205, although this does not weaken his generally sound argument.

$5^{2} \quad$ For a Muse at the handing over of the child Dionysos, see above Chapter 5 , note 59 .

53 Compare Lindblom 2011, 68: "No doubt, the child satyrs have to be the ultimate consequence of a sexual relation between satyrs and women". Also "... the satyrs ... should be counted as presumptive and capable lovers of the women that they are shown interacting with on Attic red-figure vases." Some tragedies also make reference to children sired out of wedlock in a Dionysiac context: Schlesier 2010, 215-217.

54 For comparable conclusions concerning the case of twins, see Isler-Kerényi 2007, $120 \mathrm{f}$.

55 The first version of what follows will be published in the forthcoming Festschrift for Michalis Tiverios. For that version as for the present one, I do not claim the documentation to be exhaustive. 


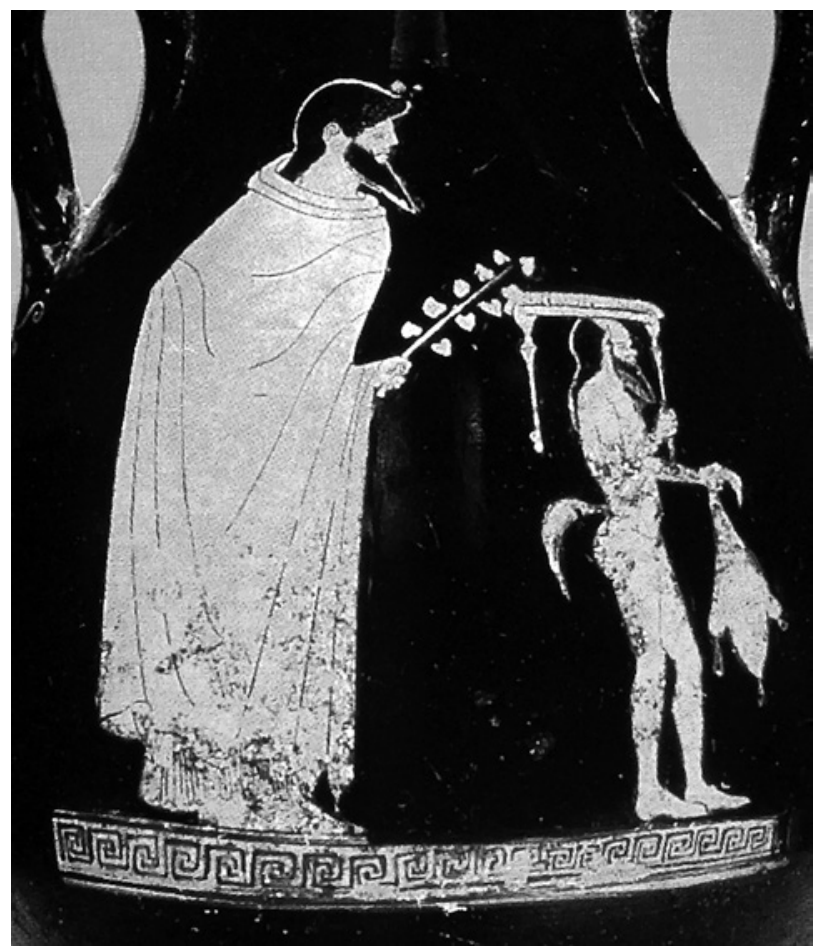

FIGURE 75 Pelike, art trade, side A (Sotheby's, London 1995, 36 Nr. 72). Photograph Courtesy of Sotheby's, Inc. (C) 1995.

\section{A Satyr Carrying a Chair}

Our first example is a sumptuous column krater by the Pan Painter, dated 480 BC or shortly afterwards. ${ }^{6}$ On the main side Dionysos, dressed in a white himation and crowned with an ivy wreath, strides solemnly towards the left. He is followed by a satyr who has a kantharos and an ivy branch in his left hand, and with his right balances an upholstered chair, a diphros, over his head. On the other side of the vase an ithyphallic satyr comes towards them carrying a large, apparently full skyphos. The image carrier calls to mind the symposium: one could almost think Dionysos was expected there. However, when participating in a symposium the god would recline on a couch and would not need a chair.

$56 \quad$ New York 16.72: Addenda 257 (551.6); BA 206281; see also a pelike, dated around 470, in the art trade, where a small bearded satyr precedes Dionysos holding the diphros over his head (Sotheby, Sale LN 5398, 06.07.1995, 36 Nr. 72), (Figure 75) as well as a small column krater in the art trade on which the satyr carrying the diphros is half dressed: Lissarrague 212 , fig. 185 . 

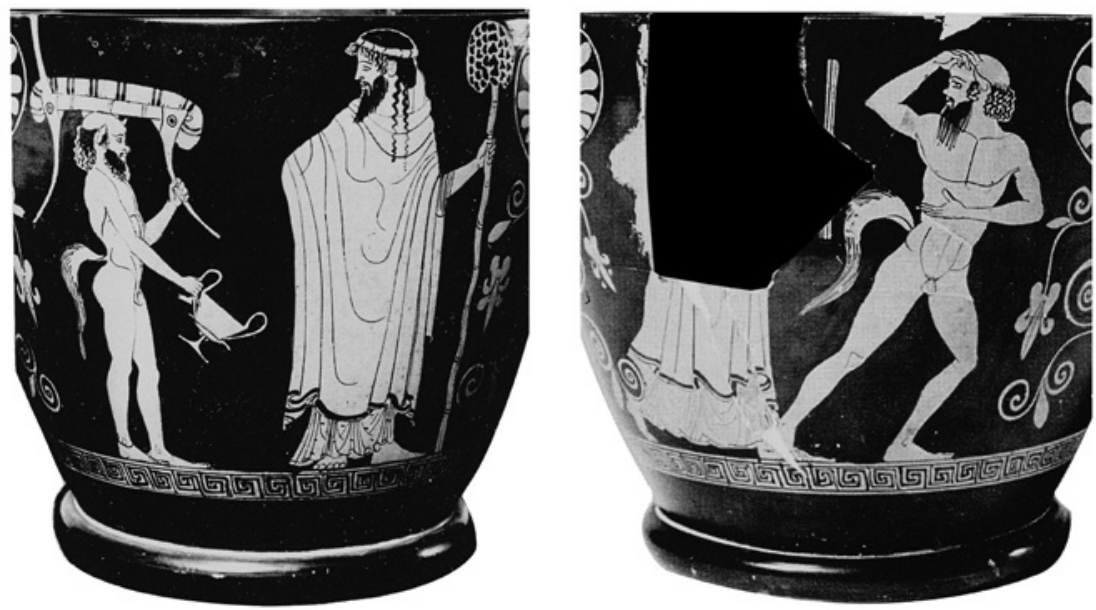

FIgURe 76 Skyphos, Lewis Painter, Moscow, Pushkin State Museum of Fine Arts II 1 b 6oo, sides A and B (cva Moscow 4, pl. 39).

The chair is not a realistic element, but a metaphoric one. When one satyr, like a faithful servant, follows Dionysos with his chair (or precedes him as on the pelike), and another one receives him with wine, this expresses the expectation that the god will join the fold of satyrs.

Quite comparable is the image on a skyphos typical for the Lewis Painter, which may be dated around 450 вс (Figure 76 ). ${ }^{57}$ Here, too, Dionysos walks in front, again in a white himation and with a thyrsos in his left hand. Turning his head, he looks at a small bearded satyr, who carries a kantharos in his right hand and with the left supports the curved leg of an upholstered easy chair, a klismos, which he balances on his head. The reverse side, disfigured by a stray fragment inserted by a restorer, a satyr moves to the right, but looks back towards a woman with a torch who is following him. His skopeuma gesture, typical for archaic-period satyrs, can, however, hardly be meant for her, but must be for the god. ${ }^{58}$ Accordingly, both sides should be read as a single procession, with Dionysos and his small satyr servant following the bigger satyr and the torch-bearing woman. ${ }^{59}$

57 Moscow II 1b 6oo: BA 19347; cVA Moscow, Pushkin State Museum IV, 45, pl. 39, 1-4 (Russia 190).

58 See Isler-Kerényi 2004a, 36 .

59 A similar female torch bearer leading a procession can, for instance, also be found on the column krater by the Agrigento Painter in Rome, Villa Giulia 846 (ARV 575.20; BA 206620), 
On a small calyx krater of about 430 BC attributed to the circle of Polygnotos a bearded satyr of small stature follows the god, who is wrapped in his himation and carries a thyrsos in his left hand. ${ }^{60}$ The satyr has a torch in his right hand and with his left supports the klismos he carries on his shoulder. On the reverse we see a youth with a stick likewise wrapped in a mantle. Is he waiting or looking on?

The motif of the chair is also used on a bell krater of about the same time which may be attributed to the Kleophon Painter, the most important of the followers of Polygnotos (Figure 77). ${ }^{61}$ It can be dated to $440-430$ BC. ${ }^{62}$ The procession shown on this vase is composed of three participants. A woman with a torch and a thyrsos goes in front, towards the right. She looks back at the god, who is wrapped in his himation and wears a strange diadem that seems more suitable for a goddess. ${ }^{63}$ In his left hand he holds a kantharos and an ivy branch. As in all examples described here the god hides his right hand in his himation. Apparently, he does not intend to take any action. He is followed by a boy satyr who carries a klismos on his right shoulder and holds aloft an ivy branch. As is the case with many kraters of this period, the reverse side has three anonymous youths wrapped in their mantles. This very frequent motif was not some meaningless space filler, but meant to evoke an atmosphere of reverent expectancy. ${ }^{64}$

All examples discussed so far of Dionysos accompanied by a satyr carrying a chair have in common that the god is depicted as striding, but wrapped to his neck in his himation and with his right hand hidden in the garment. That hand is therefore idle, while the left hand holds the thyrsos, and in one instance also the kantharos. A mantle covering the whole of the body generally expresses a demeanor known as aidos, which may be, according to the context, piousness, dread and awe in the face of some superior power, or respectful reticence. ${ }^{65}$

and the calyx krater by the Niobid Painter in Ferrara 2891 (Addenda 266 [602.24]; BA 206956).

$60 \quad$ London E 465: Para 445 (1057.102); BA 213732 (no image); Simon 1963, 21, pl. 7.4; Oakley 1997, pl. 184 A.

61 See above Chapter 5, p. 95.

62 Cahn International AG, Sales London 24-29 June 2010.

63 Compare for instance the headdress worn by Ariadne on the skyphos by the Lewis Painter in New York, discussed in Chapter 5 , note 112. It could be a dilettantish modern replacement, but the krater is said to be intact.

64 Isler-Kerényi 1993b, 96-99, and 1996.

65 Ferrari 1990, especially 193: “... properly speaking, aidos is neither shame, nor honor, nor fear, nor disgrace, but stands in some relationship to each.” 


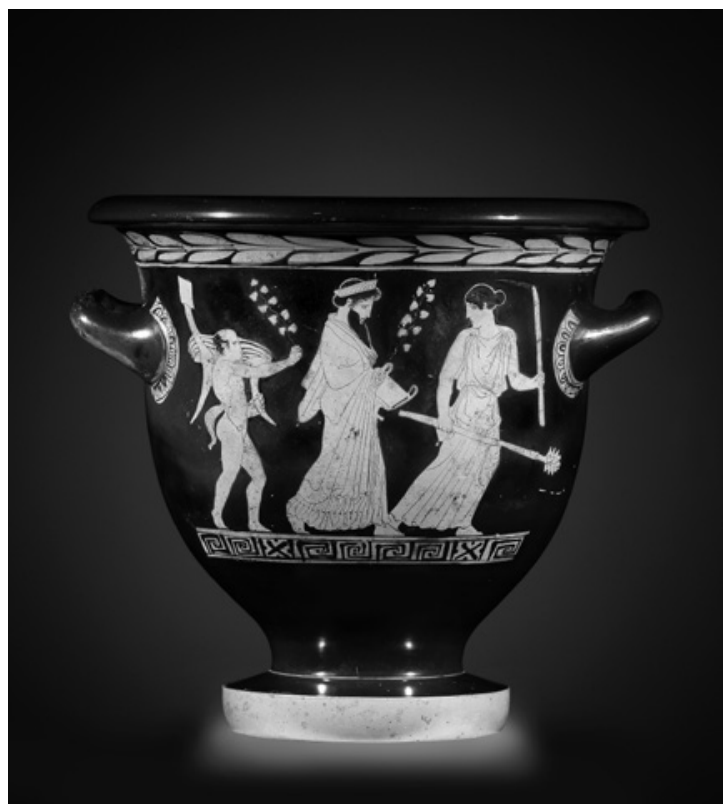

$a$

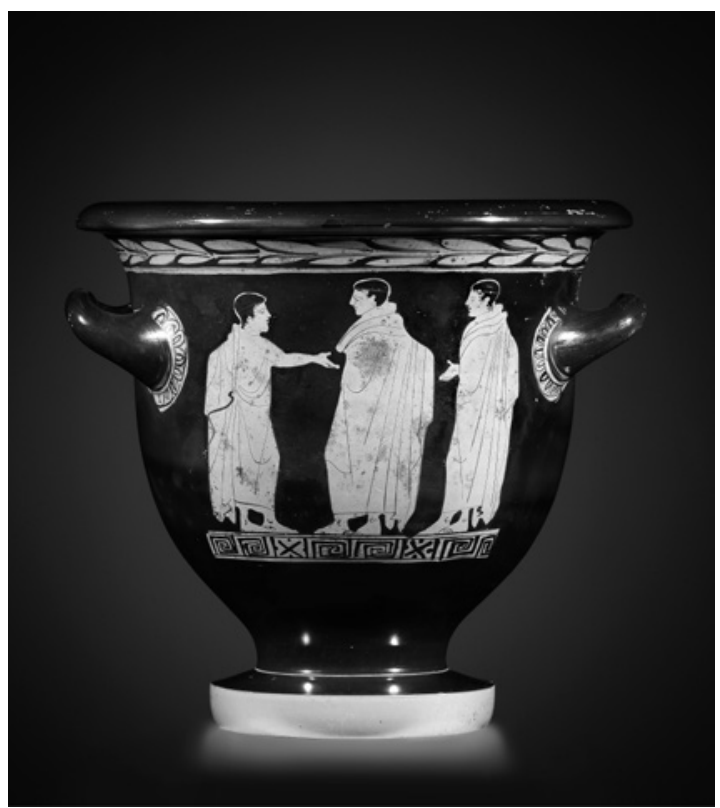

$b$

FIGURE 77 Bell krater, Kleophon Painter (?), Collection S. Rosignoli, London (photograph Nik Bürgin, reproduced with kind permission of Jean-David Cahn).

a. side $A$.

b. side $B$. 


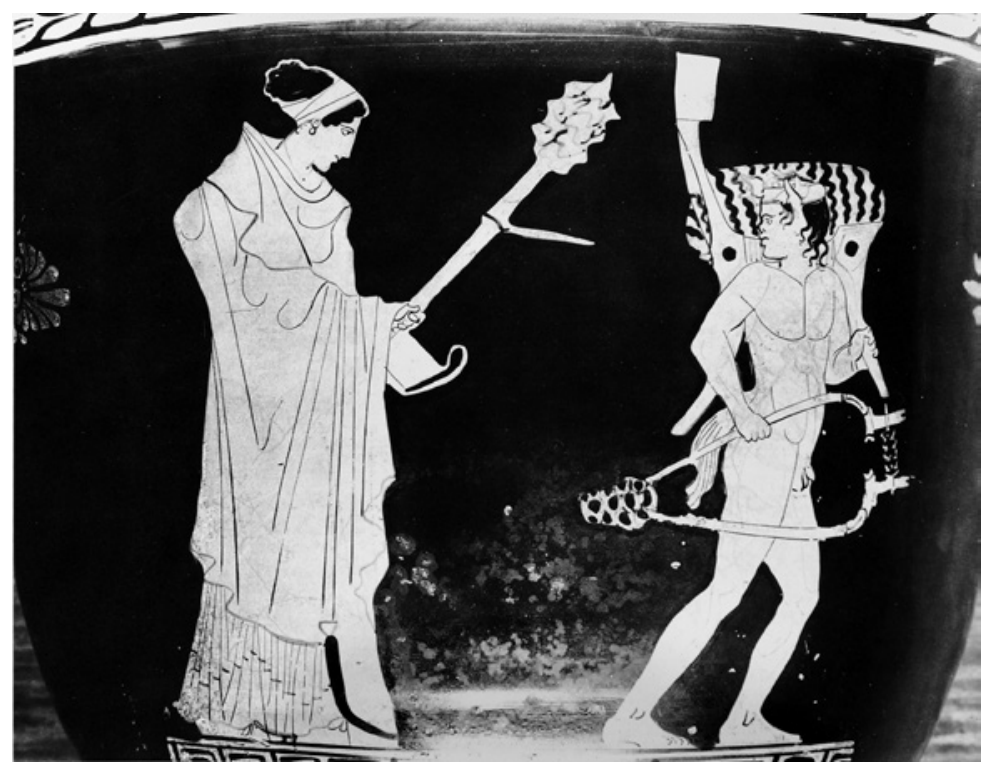

FIgURe 78 Bell krater, Phiale Painter, Paris, Louvre G 422 (Simon 1963, pl. 7.5).

Aidos is therefore a suitable attitude for those taking part in a ritual event. ${ }^{66}$ Even gods can be dressed in this manner, when they themselves are ritually engaged - as is evident from a comic depiction of Hermes at an altar. ${ }^{67}$ Thus, when Dionysos appears wrapped in his himation, he is on his way to and likely to participate in a ritual event.

In the instances discussed above, a satyr with a chair follows Dionysos as a servant, but on a bell krater by the Phiale Painter of about 440-435 BC, the satyr, moving towards the right and looking over his shoulder, precedes a woman wrapped in a himation, who holds a thyrsos and a kantharos in her left hand (Figure 78). ${ }^{68}$ This is remarkable, because usually it is the god himself who carries the kantharos, while a woman pours wine from an oinochoe to welcome him. As we will see, this unusual formula is also found in an image belonging to the third iconographic type to be discussed below. ${ }^{69}$ Here, too, the satyr is

66 For instance LIMC V.2, Hermes 101; Hermes 147; Hippothoon 10; LIMC VIII.2, Silenoi 43 a. Compare Knauer 1996, 227, note 12: "Mature muffled adults occur almost exclusively in ceremonial contexts, either as worshippers or mourners."

67 LIMC V.2, Hermes 820.

68 Louvre G 422: Addenda 315 (1019.77); BA 214255; Simon 1963, 21 f., pls. 7.5-6; Oakley 199o, 6 (for the date), 36 and 79, no. 77, pl. 59 .

69 See below note 110. 
depicted as a boy. In his right hand he holds a barbitos. He turns his head to look at the woman behind him. It may very well be assumed that the woman is on her way to meet Dionysos. Whether a wedding banquet is intended, is impossible to establish. ${ }^{70}$ Klismos and diphros are not symposium requisites, because the married women who were present used to sit at the foot of the couch. ${ }^{71}$ On the reverse a woman with a thyrsos confronts a mature satyr, who wears a himation and leans on a stick, as a citizen would do.

The motif of the citizen-satyr, which even before 450 BC already occurs several times in the work of the Geras Painter and subsequently in that of the Phiale Painter, seems to assimilate satyrs and anonymous citizens. C. Bérard and C. Bron go further and conclude that the motif in fact refers to the metamorphosis of the citizen into a satyr, a transformation that would be brought about by Dionysiac ritual. ${ }^{72}$ As was already shown in the introductory chapter above, the original viewers of Dionysiac imagery had no objections to 'normal', decent women being depicted in the role of ecstatic bacchantes or maenads, whereas male citizens who in a Bacchic context acted ecstatically or sexually uninhibited, could, because of some taboo, only be shown dressed up as satyrs-creatures of the imagination. ${ }^{73}$

That the klismos carried by the satyr is intended for Dionysos, is confirmed by the imagery of a chous from the workshop of the Shuvalov Painter, dated between 435 and 420 (Figure 79). ${ }^{74}$ The god stands on the right with his kantharos and thyrsos; his body is shown in frontal view, but his head is turned towards the left. He looks at the satyr boy approaching from the left who carries a klismos with both hands. Between the two on the floor stands a chous, which shows that the encounter takes place at the occasion of the festival of the Choes.

As to the klismos, let me quote an authoritative study of Greek furniture: "... it is the comfortable chair par excellence, less formal than the throne, more luxurious than the diphros. It is prevalent especially in scenes of women's apartments, but by no means confined to them ..." ${ }^{75}$ We could adduce many examples of the period under discussion here to support the statement that

\footnotetext{
$70 \quad$ Simon 1963, 21.

71 As they do, for instance, on the London cup by the Kodros Painter discussed earlier: see above Chapter 5 , note 42 .

72 Bérard/Bron 1986, 24-26.

73 See above Introduction, note 15.

74 Rome, Villa Giulia 50511: BA $5^{26}$ (no image); Simon 1963, 21, pl. 7.3; Lezzi-Hafter 1976, $111 \mathrm{~S}$ 96, pls. 137 C-D.

75 Richter 1966, 33.
} 


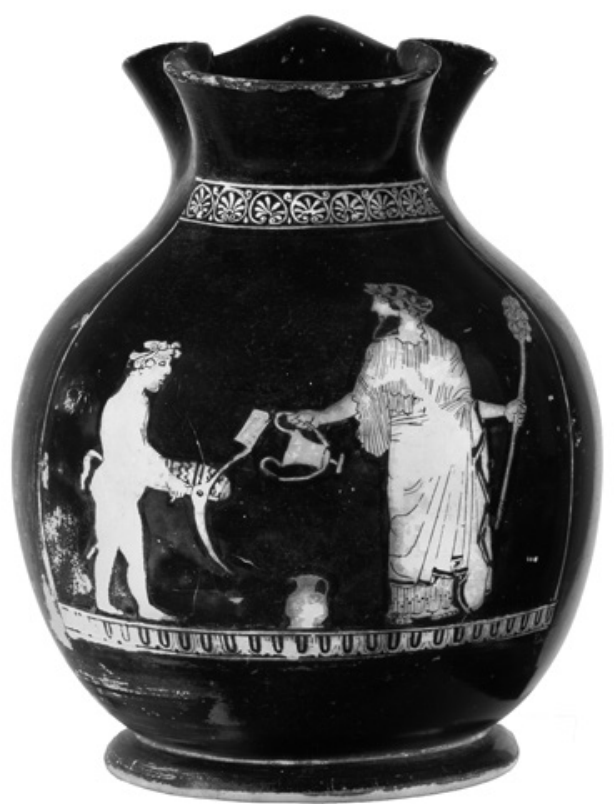

FIGURE 79 Chous, Rome, Museo Nazionale Etrusco di Villa Giulia 50511 (photographs Soprintendenza per i beni archeologici dell'Etruria meridionale).

this piece of furniture above all evokes the female quarters. ${ }^{76}$ But as the klismos was also used in other settings, it would be wrong to associate some kind of chair ritual with women only. However, we can conclude that, whenever a chair is brought in for Dionysos, this implies that the god came from elsewhere, which in turn suggests that his presence is not permanent and a matter of course. Another implication is that Dionysos, as the only one among the gods, was expected to visit people and be with them in their everyday lives.

\section{The Unoccupied Chair}

No other kind of vase is so strongly associated with one of the well-known Athenian Dionysos festival as the chous with the festival of Choes. ${ }^{77}$ Many of these small jugs show some combination of characteristic motifs: the small

76 Lissarrague 1998, 182: “Ce meuble à lui seul ... suffit presque à désigner le gynécée.” A very striking example may be found on another skyphos by the Lewis Painter: Addenda 310 (975.38); вА 276060.

77 Schmidt 2005, 152-221 also provides the earlier literature. The relationship between the chous and the Anthesteria develops gradually and is particularly evident after $430 \mathrm{BC}$, see especially pp. 174-186. 


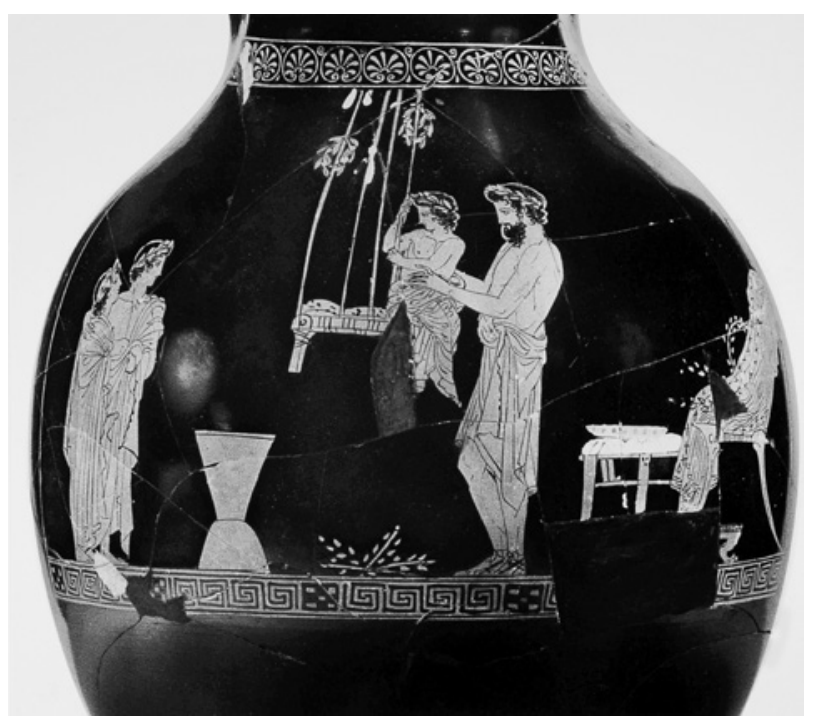

FIgU RE 80 Chous, Eretria Painter, Athens, National Archaeological Museum Bs 319 (photograph National Archaeological Museum, Athens, Spelios Pistas) (C) Hellenic Ministry of Culture and Sports/Archaeological Receipts Fund.

child, the jug, the table with gifts, etc. ${ }^{78}$ However, four of the much less numerous larger choes, between 21 and 23 centimeters in height, carry unique images depicting ritual ongoings. ${ }^{79}$ As both the actors and the accoutrements differ, it seems clear that this is not one and the same ritual. On two of the large-size choes the klismos makes an appearance.

A very fine large chous by the Eretria Painter, dated to $430-425$, is decorated with a swing ritual in which a father figure and boys of various ages take part (Figure 80). ${ }^{80}$ Near the right hand edge of the image we see an outsize easy chair with colorful cloths and laurel wreaths on it. Under the chair stands a footstool and next to it a three-legged table with three cakes and a gilded bowl. Apparently the ritual — a mature man in an artisan's outfit puts a small boy on an improvised swing with two somewhat older boys looking on-is performed

78 Hamilton 1992, 83 .

79 Athens вs 319 (ex Vlastos): Schmidt 2005, 178, fig. 91 (Eretria Painter); Athens BS 318 (ex Vlastos): Schmidt 2005, 183, fig. 93 (Eretria Painter); Athens, 3rd ephory, inv. 3500: Schmidt 2005, 184, fig. 94 (Eretria Painter); New York 75.2.11: Schmidt 2005, 177, fig. 90 (Meidias Painter).

8 Athens bS 319: BA 216950; Lezzi-Hafter 1988, 198-201 and 339, no. 214, fig. 66, pl. 136. Schmidt 2005, 178 dates it around 430-420. 


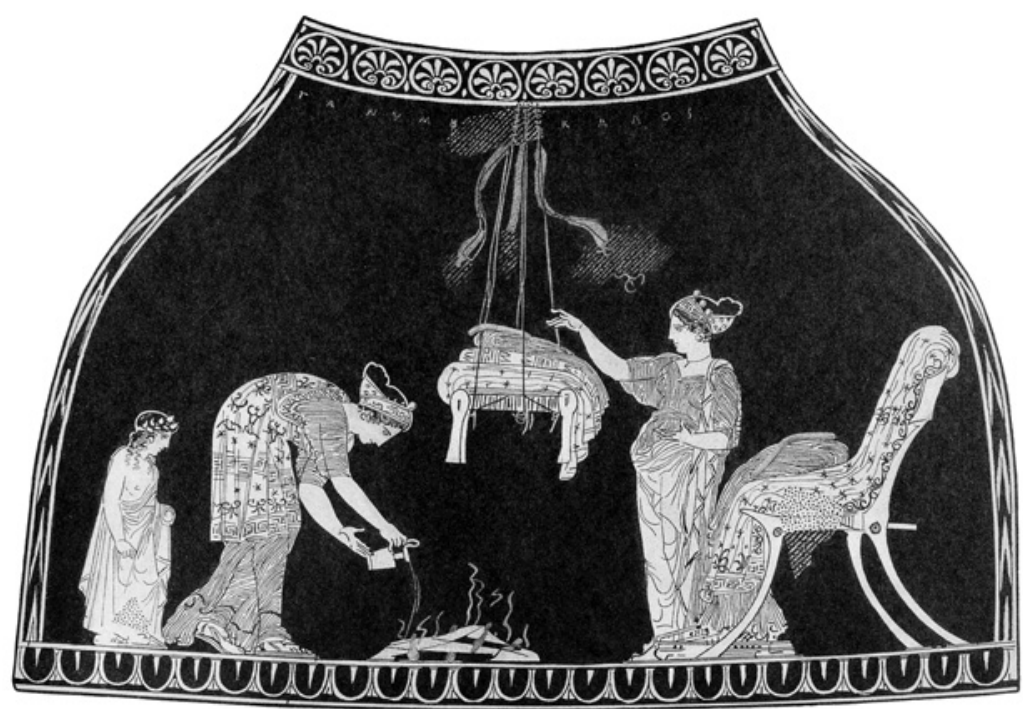

FIGURE 81 Chous, Meidias Painter, New York, Metropolitan Museum of Art 75.2.11 (Richter 1936, pl. $158 a)$.

in the expectancy of a visitor, someone for whom the chair with the festive cloths and the gifts on the little table are meant. ${ }^{81}$

The swing, in the center of the image, and an even larger klismos can also be found on a slightly younger chous by the Meidias Painter. ${ }^{82}$ Costly fabrics lie folded on the swing. These are impregnated with perfumes poured onto burning twigs. On the left a boy approaches, wreathed and dressed in a festive himation (Figure 81).

Although both images with swings appear to refer to an actual ritual, it has proved impossible to identify them with any ritual known from our written sources. ${ }^{83}$ In any case, the unoccupied chair indicates that during the Anthesteria women, men, and boys were preparing for the arrival of the god in a festive mood. Whether the swinging was performed in memory of the tragic death of Erigone should for now remain an open question. ${ }^{84}$ Still, it certainly transports us to a Dionysiac sphere. In swinging, as in dance, one is lifted up, raised above the ground, and finds oneself between up and down, back and

\footnotetext{
81 See Schmidt 2005, 179 and $185 \mathrm{f}$.

82 New York 75.2.11: Addenda 362 (1313.11); BA 220503; Lezzi-Hafter 1988, 201 f. and 341, no. 225, pl. 195 d; Schmidt 2005, 177, fig. 90, dated 420-410 BC.

83 Schmidt 2005, 178-180.

84 For critical comments see Humphreys 2004, 242 f.; Schmidt 2005, 179.
} 


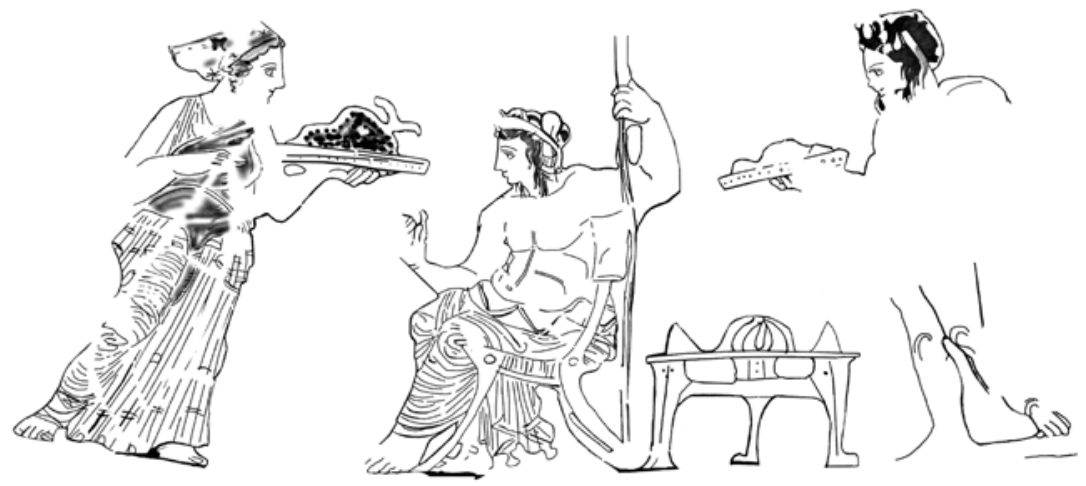

FIGURE 82 Chous, artist from the sphere of the Dinos Painter, excavation number A 115 (Hatzidimitriou 2012, 121, fig. 4, drawing K. Deli).

forth - symbolically in a state of transition, a state brought about by Dionysiac metamorphoses, for instance from one age group into another. ${ }^{85}$

The chous by the Marsyas Painter, some two generations younger, is not the only source to show that the empty chair is meant for Dionysos and not for the Basilinna. ${ }^{86}$ The chous shows a youthful Dionysos seated on a klismos standing on top of a low platform. He turns towards an alluring female figure on his left, who is identified by an inscription as Pompe ('procession'). On the far left, Eros is putting on his sandals next to a large sacrificial basket. Apparently, the woman here personifies a complete procession, on its way to ritually unite with Dionysos. This particular image can only be read symbolically, but there is another one, only recently published, that is closer to real life.

This concerns the decoration of a large chous of which only the lower half has been preserved. It was found in 2010 in Trachones near Athens, and is likely to have been a grave gift. It has been attributed to the circle of the Dinos Painter and dated to $420-410$ (Figure 82 ). ${ }^{87}$ A youthful Dionysos dominates the center of the image. He wears a fillet tied over a wreath of leaves. He sits on a klismos, turned towards the left and with a thyrsos in his left hand. Whether he also held something in his right hand is now impossible to tell. ${ }^{88} \mathrm{~A}$ woman approaches from the left. She wears an animal skin over her chiton, and has her hair in a decorated coif. With her outstretched left hand she offers the god

85 Isler-Kerényi 2007, 59 and $214 \mathrm{f}$.

86 Similarly Schmidt 2005, 176-180; New York 25.190: BA 503 (no image); Schmidt 2005, 191 f., fig. 98; Smith 2011, 86 and 171 VP 58.

87 Hatzidimitriou 2012.

88 Hatzidimitriou 2012, 118. 
a plate with a giant bunch of grapes. A satyr carrying a plate of sweetmeats approaches from the other side. In front of him, near the god's klismos, we see a low three-legged table with more pastries. It is very similar to the table on the chous with the boys' swing ritual just discussed. ${ }^{89}$ The situation is unambiguous: the god has arrived, sits on the chair that had been prepared for him, and accepts the gifts of his believers. The prominent bunch of grapes, also a recurrent motif on small choes, should, of course, not be taken in a literal, but in a symbolic sense: even in Greece there were no ripe grapes in spring, at the time of the Anthesteria. ${ }^{90}$ The grapes would rather refer to the young wine in the choes - wine made from the grapes of Dionysos.

Within the series of images presented here, the one just discussed is of particular importance because it is close to that on a more or less contemporaneous bell krater by the Pothos Painter belonging to another iconographic tradition to which we will turn now. ${ }^{91}$ From the imagery explored above we can conclude that the chair is associated with Dionysos and that it was somehow part of the Anthesteria — symbolically, but possibly in actual ritual practice. ${ }^{92}$

\section{Dionysos Has Arrived}

Thus, Dionysos was expected during the Anthesteria and when he came, he was received with gifts. The easy chair prepared for him indicates he came in order to stay. Of the arrival, or epiphany, of the god and his being greeted with a libation by a woman or a satyr, there are countless examples in Dionysiac iconography, ever since vase painting began. ${ }^{93}$ Usually, however, the protagonists are shown standing - although for black- and red-figure cups Dionysos sitting amidst his thiasos was a popular motif. ${ }^{94}$ After 450 BC, in work by or inspired by Polygnotos, we encounter a new version of the god's arrival that explicitly refers to a reception ritual.

As a first example let us consider an early stamnos by Polygnotos. ${ }^{95}$ The center of the image shows Dionysos, his name inscribed, sitting on a folding chair, and a veiled woman who fills the god's kantharos from her oinochoe.

89 See above note 80.

$90 \quad$ Similarly Hamilton 1992, 116.

91 Madrid 11052: Addenda 341 (1188.4); BA 215738 (no image); Queyrel 1984, 134 f., no. 20, fig. 19.

92 Compare also, for instance, the small neck-amphora in Brussels R 249: ARV 668.38; BA 207833 .

93 The earliest known example is an impressive Cycladic vase from the late 7 th century, see Isler-Kerényi 2007, figs 1-2.

94 Compare in addition the medallion image of the Florence cup, see above 124 fig. 68a.

95 Louvre G 406: Addenda 317 (1028.12); BA 213393; Matheson 1995, 34, fig. 22 (dated 450-440). 

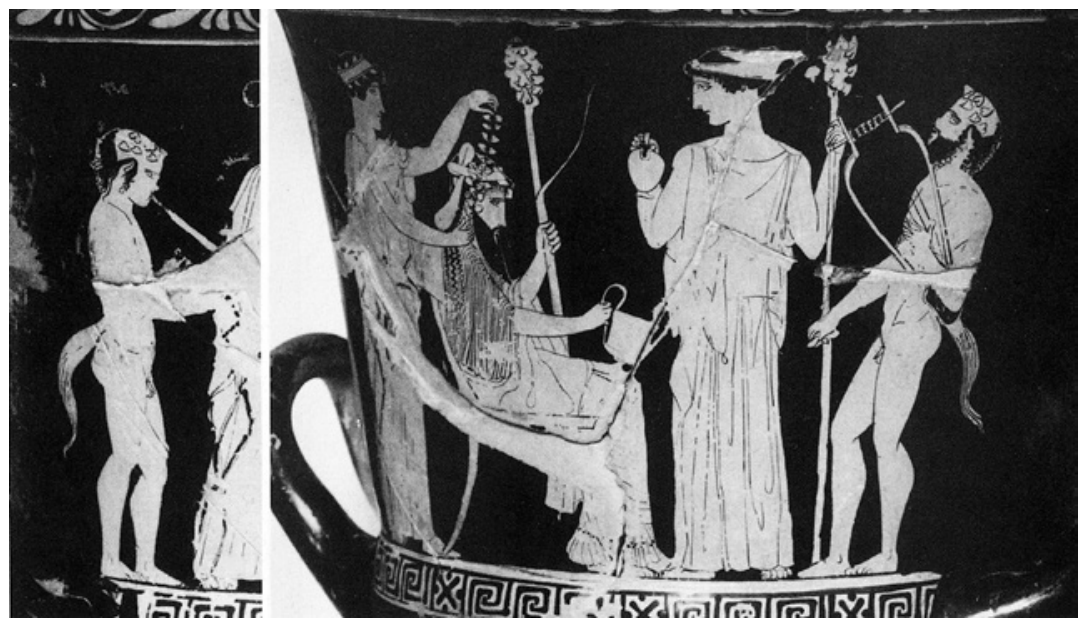

FIGURE 83 Calyx krater, Polygnotos group, Copenhagen, The National Museum of Denmark ABC 1021, side A (cVA Copenhagen 4, pl. $146 a-b)$.

The inscription "Arsin..." possibly refers to Ariadne. The god wears a voluminous headband over his wreath of leaves and holds the thyrsos in his left hand. Instead of a chiton, the woman wears a peplos with a decorated border. On the right a satyr energetically strides towards them, carrying a torch in his left hand. He lifts his right arm in surprise — or is he supposed to be dancing? On the left another satyr approaches, strumming the barbitos. On the reverse, three women are quietly standing about: one with an oinochoe, the middle one with a thyrsos, and the one on the right with a torch. Both images have an air of reverence.

A calyx krater of about the same date is quite comparable (Figure 83). $\cdot{ }^{96} \mathrm{In}$ the center of this symmetrically composed image we find Dionysos on his klismos, again with a large headband tied over an ivy wreath, with a kantharos in his right and a thyrsos in his left hand. Before him, shown en face, is another peplos-clad woman with a thyrsos in her left hand, her hair beautifully done up. She pours wine for the god from her oinochoe. A second woman in a peplos, wearing a costly diadem, lifts both hands in order to crown Dionysos from behind with another ivy wreath. From the right a singing satyr is approaching with a barbitos, from the left comes a younger, beardless satyr playing the aulos. Both satyrs are smaller than the women, and therefore cannot be adult satyrs. On the other side of the vase, the center of the image is occupied by a

96 Copenhagen ABC 1021: Addenda 318 (1035.2 and 1037.1); BA 213467; Bérard/Bron 1984, 140, fig. 201; Matheson 1995, 164. 
woman dressed in chiton and himation. Her hair is in a coif and she holds a thryrsos. On her right a satyr with a kantharos, and on her left one with a torch. Both satyrs wear the himation of the citizen. In these images, too, there is pious calm.

Another stamnos, from the circle of Polygnotos and likewise dated between 440 and 430 , carries a comparable scene. ${ }^{97}$ On the far left, Dionysos is sitting on a klismos covered with an animal skin. He wears an ivy wreath and again holds the kantharos in his right hand and the thyrsos in his left. Before him, in frontal view, stands a young beardless satyr, who pours the god a drink from an oinochoe, while holding a wine skin in his left hand. To his right follows a maenad wearing and ivy wreath, a fawn skin over her chiton and a richly embroidered robe. She has lighted torches in both hands. She looks back towards another satyr, this one bearded, who approaches from the right, singing and playing the barbitos. The maenad's name is inscribed as Helike, both satyrs are called Marsyas. On the reverse, we again find the woman in the coif, holding a long branch. To her left and right are two naked satyrs. The one on her right seems to be gesticulating. She may be having a conversation with him.

A fragmentary stamnos by the Hector Painter also belongs to this series. Of Dionysos, who sits on the left wearing an ivy wreath, only the head and

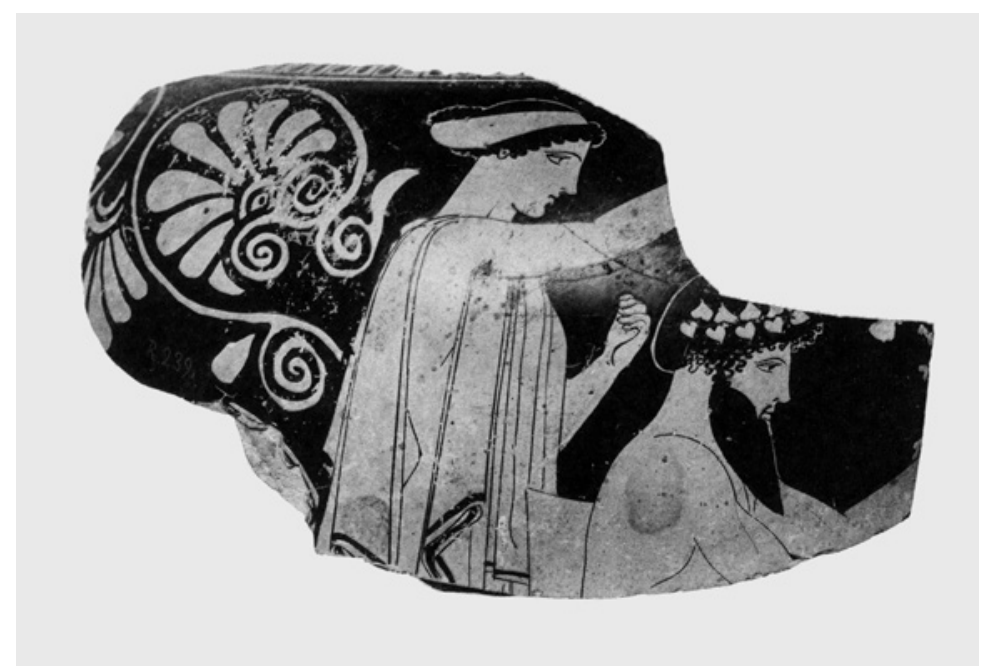

FIGU RE 84 Fragment of a stamnos, Hektor Painter, Brussels, Musée d'Art et d'Histoire R 239 (cva Brussels 1, III ID, pl. 1.2).

97 New Haven (Ct), Yale University 1913.132: Addenda 318 (1035.4); BA 213471; Matheson 1995, 116, fig. 98 (Midas Painter). 
shoulders are preserved. He is crowned by a woman in a peplos standing behind him (Figure 84).98

An original variation on the scheme discussed above may be found on an exquisite bell krater from the same circle, likewise dated between 440 and 430 BC. ${ }^{99}$ This image, too, shows Dionysos being greeted by two women. Seated on his klismos, he has drawn towards himself a child satyr whom, like a father, he gives a taste of wine from his kantharos. Satyrs of various ages figure regularly in the images discussed here, and continue to appear during the second and third quarter of the century. ${ }^{100}$ This is hardly surprising. As stated above, in vase painting satyrs are substitutes for citizens taking part in Dionysiac rituals-bacchants. ${ }^{101}$ Childlike and young satyrs fit into this world of vase imagery just as readily as boys and young men. The name Komos is used repeatedly for satyrs in vase painting after $450 \mathrm{BC} .{ }^{102}$ It refers to the wild, euphoric parading before and after the symposium, something the little drinker can look forward to as he grows up.

When the woman pouring wine to the right of the central group is referred to as Ariadne, this implies a close relationship with the god. However, it does not necessarily mean that the scene has shifted from a human to a separate, mythological plane. In the transition from one age group to the next or one status role to another, any woman could identify with Dionysos' bride Ariadne. ${ }^{103}$ For the modern viewer, the name Tragoidia for the woman who is playing with a hare on the left remains enigmatic. ${ }^{104}$ The depiction of Dionysos as a father in the context of a wine ritual is unique and very striking.

\footnotetext{
98 Brussels R 239: ARV 1036.9; BA 213480; Matheson 1995, 102 and 105, fig. 83.

99 Compiègne 1025: Addenda 322 (1055.76); BA 213708; Moraw 1998, 90 and 296, no. 398, pl. 18, figs 47a-b; Matheson 1995, 165; Lissarrague 2013, 35 f., fig. 15.

100 Lissarrague 1998, 186-196.

101 Isler-Kerényi 2004a, $61 \mathrm{f}$., and in addition the Introduction above, note 15.

102 LIMC VI.1, 96 f., Komos 6-20.

103 Isler-Kerényi 2007, 123.

104 For other Dionysiac women with this name, see Schmidt 2005, 189-191; LIMC VIII.1, 49, Tragoidia $7-10$. It is well known that the hare, as pet, love gift, or catch was a common reference to the erotic. It was already used as an attribute for Dionysiac nymphs in the Archaic period, see Isler-Kerényi 2007, 134 and figs 7, 63, 69, and 70. But even if one keeps in mind that Attic tragedies not always have a tragic ending, one may wonder what a figure that evokes a genre that is anything but lighthearted is doing with a hare. However, in view of the fact that the performance of tragedies was part of the ritual of the Athenian Dionysiac festivals, the presence of Tragoidia in a Dionysiac context is not remarkable: Lissarrague 2013, $35 \mathrm{f}$.
} 
A comparable composition as well as a Dionysiac father may be found on the equally magnificent, but fifteen or twenty years older, bell krater attributed to the Altamura Painter. ${ }^{105}$ The comparison with this krater confirms that the Dionysos on the klismos of the Compiègne bell krater should indeed be seen as a father figure. It seems, therefore, plausible that the seated Dionysos in the scenes we have just discussed was seen above all as someone fatherly — this in contrast to his role in the Bacchic thiasos.

To these four more or less contemporaneous representations of the seated Dionysos celebrated by women and satyrs, we can add a bell krater of about 420 BC attributed to a later Polygnotos circle. ${ }^{106}$ Again Dionysos (his name is inscribed) seated on a klismos is the main protagonist. Again he wears the ivy wreath and holds the thyrsos-but here he is portrayed as a bare-chested young man with cropped hair. His rejuvenation, often remarked upon before, has apparently taken place sometime between 440 and $420 .{ }^{107}$ It can be convincingly connected to the new Dionsyos as represented on the east pediment of the Parthenon; an image with which Phidias surprised the Athenians in or shortly before $43^{2}{ }^{108}$ The fatherly role attributed to the god on somewhat earlier vases is no longer compatible with this youthful Dionysos. From now on he is rather the longed-for lover. ${ }^{109}$

In this same image there is a woman whose name is inscribed as Bakche. She wears a simple headband over her short hair. With her right hand she offers the god a kantharos, in her lowered left hand she holds an oinochoe: a surprising change of attributes, difficult to account for, but not unique as can be seen from a bell krater by the Phiale Painter, already mentioned above. ${ }^{110} \mathrm{~A}$ second woman, named Orania, seems to touch the back of the god's head. Her long loose hair appears from under her fillet and she lifts a large tympanon in her left hand. A satyr, designated as kalós, comes from the right while playing the aulos. The reverse image shows three young men in their himatia. An aryballos and a strigil over their heads evoke the world of the gymnasium. All three are characterized as adolescents: beardless and with uncut hair. The middle one, wrapped in his himation to his neck, seems to listen to his gesticulating companion on the right, while the third one, likewise fully covered, approaches from the left. The mood of pious expectation, common to numerous scenes

\footnotetext{
105 Ferrara 2738: see above Chapter 5, note 64 and p. 105 fig. 55 .

106 London E 503: Addenda 337 (1159); BA 215344; LIMC III.1, 8o Bakche 2.

107 Queyrel 1984, 157; Matheson 1995, 187.

108 Carpenter 1997, 92; see below Chapter 7.

109 Isler-Kerényi 2011a, 81-84.

110 See above note 69 .
} 
such as this one, is quite palpable here. It befits the celebration of Dionysos depicted on the main side of the krater.

All images explored in these paragraphs have in common that they present Dionysos in an ordinary human environment where he is honored with ritual acts; the reverse sides of these vases show pious quiet instead of the boisterous thiasos. Taking part in these acts are satyrs of various ages and women in a range of different garments. These, too, are probably representative of various age groups and/or social positions. It is unlikely that we will ever know if these images refer to a specific reception rite. We can merely point at the fact that, of all the gods, the vase painters only depicted Dionysos in this way, thus highlighting his closeness to ordinary mortals.

The motif of the seated Dionysos who is ritually greeted, is continued in the work of the Kadmos Painter and the Pothos Painter. A somewhat mediocre bell krater by the Kadmos Painter, dated after 430 BC, is decorated with a bearded Dionysos sitting hieratically on a klismos with a kantharos in his right hand and a thyrsos in his left. ${ }^{111}$ The libating Nike comes flying from the right, in front of him a tame feline crouches on the floor. The scene is framed on either side by satyrs. The bearded one on the left plays the aulos, a lyra at his feet. The one on the right is younger. On the reverse we again see three youths wrapped in their himatia.

Quite comparable are three, likewise rather mediocre, bell kraters by the Pothos Painter, from the early fourth quarter of the century. On two of these the god is shown bearded, with kantharos and thyrsos; a maenad pours him wine from an oinochoe. ${ }^{112}$ A satyr and other women frame the scene. It is hardly surprising that this obviously conservative vase painter preferred to stick to the traditional formula of the bearded god as long as was viable. All the more remarkable is the third vase on which Dionysos appears beardless, almost naked, and facing left instead of right as in all other images discussed here, with the exception of the chous from Trachones. ${ }^{113}$ Moreover, the god is not received with a libation from an oinochoe, but with a gift of grapes. ${ }^{114}$ In this way the vase clearly appears to be iconographically related to the chous

\footnotetext{
111 Madrid 11074: ARV 1185.17; BA 215705.

112 Vienna 1065: ARV 1188.3; BA 215737 (the main image incorrectly shows Madrid 11052); Queyrel 1984, no. 16, 133, fig. 15; Tapley Park (Devon): ARV 1188.2; BA 215736; Queyrel 1984, no. 21, 135, fig. 20.

113 Madrid 11052: Addenda 341 (1188.4); BA 215738 (no image); Queyrel 1984, no. 20, 135, fig. 19.

114 Queyrel 1984, 154. Compare the dinos by the Dinos Painter, Berlin 2402, and the volute krater by the Kadmos Painter, Ruvo 1093: Queyrel 1984, 152, figs 28 and 29.
} 
mentioned above, so that the whole set of images may be linked to the Anthesteria imagery featuring a chair.

However, the three examples by the Pothos Painter show a further innovation: the god is no longer seated on a klismos, but on a little knoll. The scene has, consequently, lost relationship with the human household. It has shifted to a mythological level — and there it will remain in both Attic and Apulian imagery. To evoke reverent expectation, in a general way, three youths in their himatia always decorate the reverse side. The formula will subsequently be taken into the early 4 th century by the Meleager Painter. ${ }^{115}$

To sum up: there are three series of images sharing the element of the chair of Dionysos. The first and earliest shows the chair being carried by a satyr in the god's retinue; the second exclusively attested by the choes of the period between 430 and 410 , shows the klismos-empty at first, later occupied-in the context of the Anthesteria; the third shows the seated god ritually greeted by his venerators. The chous from the workshop of the Shuvalov Painter links the first and the second series, and the recently discovered chous from Trachones the second and third. In Athens during the second half of the $5^{\text {th }}$ century, three different formulae were, therefore, used to evoke the arrival of the god at the Anthesteria. Apparently, this was not part of public polis religion, but a ritual in the domestic sphere, in which several family members were engaged: children, young girls and married women, and, in the guise of satyrs, young and adult men. ${ }^{116}$ Possibly, the chair was not merely an element of the imagery, and thus a mental category, but also part of the actual ritual.

We have to keep in mind that, of all the gods who are represented in vase painting as seated on an elegant klismos, only Dionysos has it carried before him; and only Dionysos has a chair prepared for him with cloths and gifts: no other god's arrival is expected. Only Dionysos' arrival is ritualized in this way: he is the only god who always returns to visit people's homes. The first Dionysos chair that is not domestic but plays a part in polis life is depicted on a bell krater by the Kadmos Painter from just before 400 в . ${ }^{117}$

\footnotetext{
115 See, for instance, Kathariou 2002, 391-440, figs 14, 17, 18, and 40.

116 It seems advisable, therefore, to take into account that rituals, including those of the Anthesteria, changed over time: Humphreys 2004, 223-225.

117 See below Chapter 8, note 25 .
} 


\section{Child Satyrs in Dionysos' Retinue}

Although satyrs of various ages are not a particularly popular motif, satyrs as child, boy or youth appear regularly in vase painting between 480 and $430 .{ }^{118}$ If one understands satyrs to be men in a Dionysiac context or a Dionysiac mood, it need not surprise that the newborn male, naturally an untamed being, can also appear as a small satyr. ${ }^{119}$ We saw this on a stamnos by the Phiale Painter. ${ }^{120}$ We could see all this as an illustration of the human trait of going through changes during one's life cycle, i.e. of one's Dionysiac nature.

Some images from around $450 \mathrm{BC}$ allow us to observe changes in the lives of satyrs. This is not about those images that refer to satyr plays, but about images that refer to Dionysiac ritual. ${ }^{121}$ On a calyx krater by the Villa Giulia Painter we see a Dionysiac procession (Figure 85$).{ }^{122}$ In front, on the left hand side of the image, goes a white-haired satyr by the name of Marsyas, playing the aulos. Next comes a boy satyr, named Posthon, with a lighted torch. ${ }^{123}$ Behind him comes a pensive woman, named Mainas (i.e. Maenad) with a thyrsos in her right hand and a kantharos in the left, and finally an adult satyr, Soteles, also with thyrsos and kantharos, who is singing with his head thrown back. The involvement of satyrs of three age groups in a ritual event, the festive nature of which is palpable, cannot be made more explicit. ${ }^{124}$

Boy satyrs also often appear in a Dionysiac context with one single maenadlike woman. On a small neck-amphora by the Phiale Painter, a woman with a thyrsos hastens towards the left behind a young satyr with a heavy wine sack. ${ }^{125}$ On another of his neck-amphorae, a young satyr wearing a wreath plays the aulos with total abandon. A maenad, also wearing a wreath, dances wildly to its music, her thyrsos planted in the ground in front of her. ${ }^{126}$

Youthful as well as adult satyrs may also accompany the god himself. One of the painters of column kraters active during the second quarter of the century presents Dionysos as a participant in a ritual procession on the main side of

\footnotetext{
118 Lissarrague 1998, 186-196 and 2013, 63-66. Lindblom 2011, 68 points at 125 vase images in an unpublished study by J. Michael Padgett.

119 Isler-Kerényi 2004a, $94 \mathrm{f}$. Also above Introduction note 13.

120 See above note 48 and 134 fig. 74.

121 Satyrs in satyr plays: Krumeich 1999.

122 Karlsruhe 208: Addenda 270 (618.3); BA 207151.

123 According to Lissarrague 1998, 191 this is a term for the penis.

124 Lissarrague 1998, 188-191, fig. 36.

125 Madrid L 188: ARV 1015.18; BA 214195.

126 Bedford, Woburn Abbey: ARV 1015.19; BA 214196.
} 


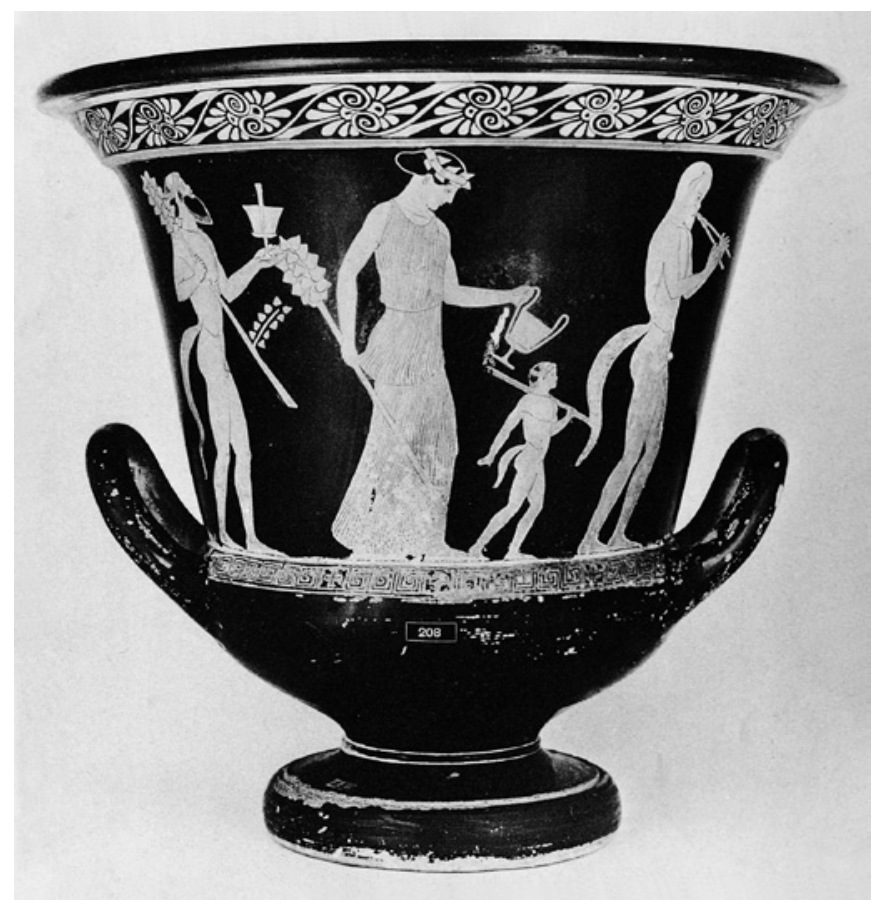

FIgURE 85 Calyx krater, Villa Giulia Painter, Karlsruhe, Badisches Landesmuseum 208, side A (cVA Karlsruhe 1, pl. 19.1).

a vase. ${ }^{127} \mathrm{~A}$ woman with a large torch in each hand moves in front towards the right. She is followed by the god, who leans on a young satyr playing the aulos. Dionysos is bearded, wears nothing but a chlamys over his left arm, and carries a thyrsos. A woman playing the lyra comes next, and she is followed in her turn by an adult satyr dancing along with a pointed amphora decorated with a wreath, and probably filled with wine. Related are a bell krater by the Methyse Painter and four somewhat later ones by the Christie Painter, who belongs to the circle of Polygnotos. They show Dionysos moving towards the right between a young satyr playing the aulos and a torch-bearing woman. ${ }^{128}$

127 Rome, Villa Giulia 846: ARV 575.20; BA 206620 (Agrigento Painter): here 75 fig. 38 . The instrument is the barbitos, see above Chapter 2, note 48 .

128 Methyse Painter: New York 07.286.85: Addenda 272 (632.3); BA 207338; Christie Painter: Vienna 782: Addenda 320 (1047.10); BA 213579; Baltimore 48.74: ARV 1047.11; BA 213580; fragments in Syracuse and Athens, private collection: ARV 1047.12 and 13. 


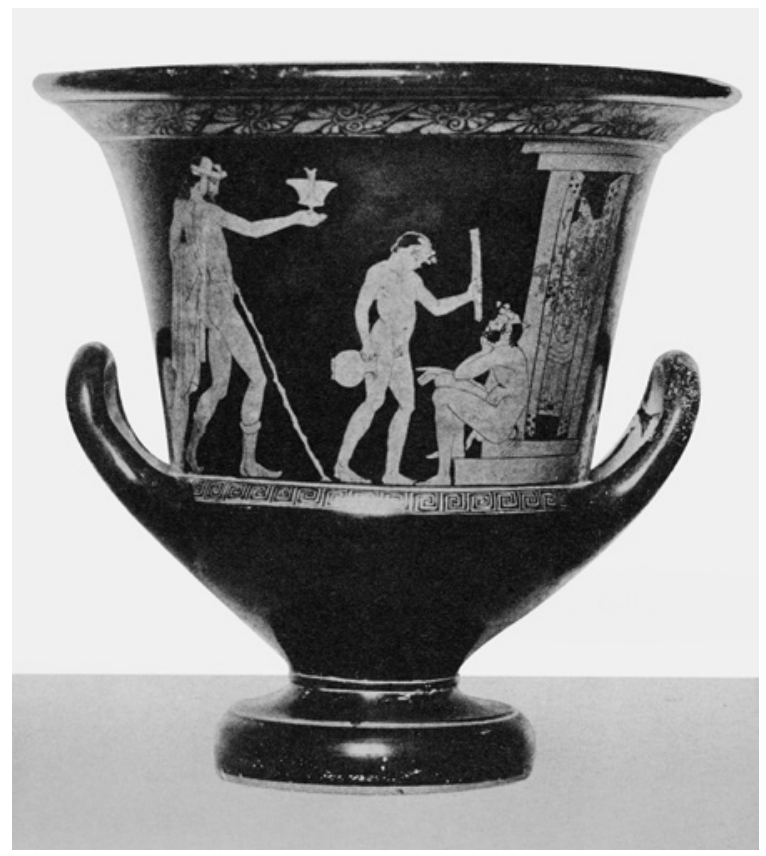

FIGURE 86 Calyx krater, group of Polygnotos, Tarquinia, Museo Nazionale Tarquinense RC 4197, side A (cva Tarquinia 2, pl. 18.3).

A unique image decorates a calyx krater of the Classical period from the circle of Polygnotos (Figure 86). ${ }^{129}$ Dionysos enters on the left. He is shown as a naked, staggering komast, with the kantharos lifted in his right hand and a gnarled stick in his left. A satyr boy with a torch in his left hand and an oinochoe in his right shows him the way to a house. It looks as if he asks the adult satyr who sits on the threshold like a guard for permission to enter. Through the halfopen door we see a seated woman, who seems to gesture with her right hand to be quiet. Her body is shown in frontal view, but her face is turned to the left. On the reverse a mature satyr, dressed as a citizen in a himation, moves in the same direction as the couple on the main side between a gesticulating woman and a woman holding a torch. It is difficult to decide whether both scenes are related. It also remains an open question whether the scene on the main side should be interpreted as the marriage of Dionysos and the Basilinna, a ritual that belongs to the Dionysiac spring festival of the Anthesteria. This interpretation could find support in the oinochoe carried by the boy satyr. ${ }^{130}$ For our

129 Tarquinia RC 4197: Addenda 322 (1057.96); BA 213726; Paul-Zinserling 1994, 44.

130 Simon 1963, 21, pl. 5.3. 


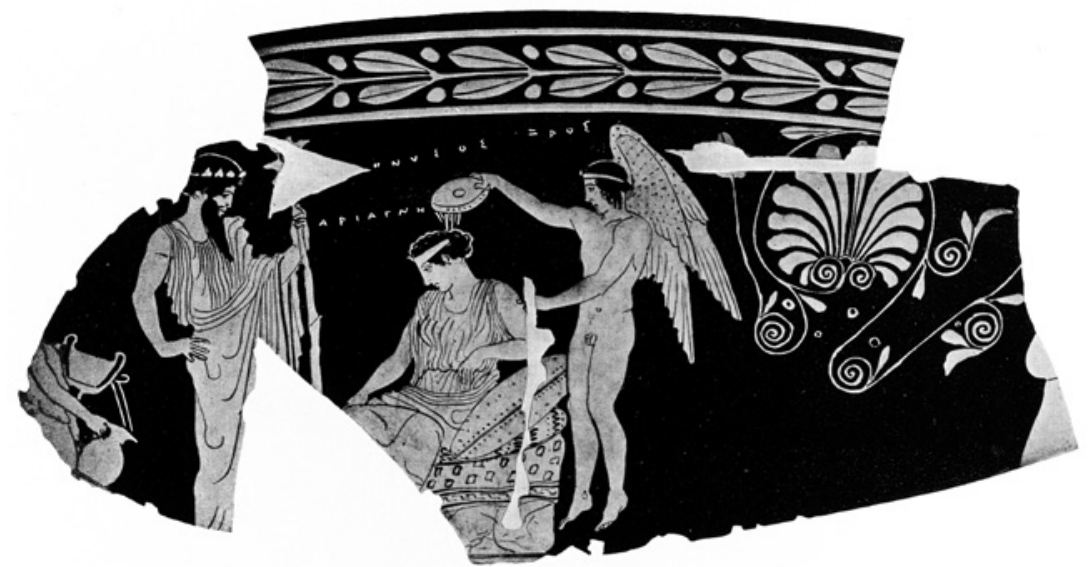

FIGURE 87 Fragment of a calyx krater, group of Polygnotos, Tübingen, Institut für Klassische Archäologie der Universität 5439 (AE 1937, pl. 1).

present purpose, however, it is not as important as the presence of a boy satyr and an adult one within the same scene. The image on a calyx krater from the same workshop, now in a fragmentary state, was probably comparable (Figure 87 ). ${ }^{131}$ It shows a young woman sitting on a bed with a pillow and a mattress. Before her stands Dionysos, crowned with ivy, leaning on the thyrsos in his left hand. Eros comes flying from the right behind the woman. He holds a phiale over her head and touches her upper arm. To the left of Dionysos we find what seems to be a small satyr, unfortunately badly preserved, with an oinochoe in his right hand and a kantharos in his left.

We already discussed Dionysos personally taking care of a boy satyr, as portrayed on a bell krater from the circle of Polygnotos. ${ }^{132}$ The name Komos seems rather suitable for the little satyr who, as an adult, will certainly take part in komoi. Once again the identity of the individual figures remains ambivalent, which seems to hold good for all denizens of the Dionysiac sphere. Instead of clarifying, the inscribed names rather serve to confirm this ambivalence.

A large chous by the Eretria Painter shows Dionysos and Hephaistos riding a mule. ${ }^{133}$ It enters on the right, led by a boy satyr, who looks back and

131 Tübingen 5439: Addenda 322 (1057.97); BA 213727. With respect to content, this image is very similar to the one by the Kadmos Painter showing Dionyos as the bridegroom, see above Chapter 5 , note 116 .

132 See above note 99.

133 See below Chapter 8, note 48 . 


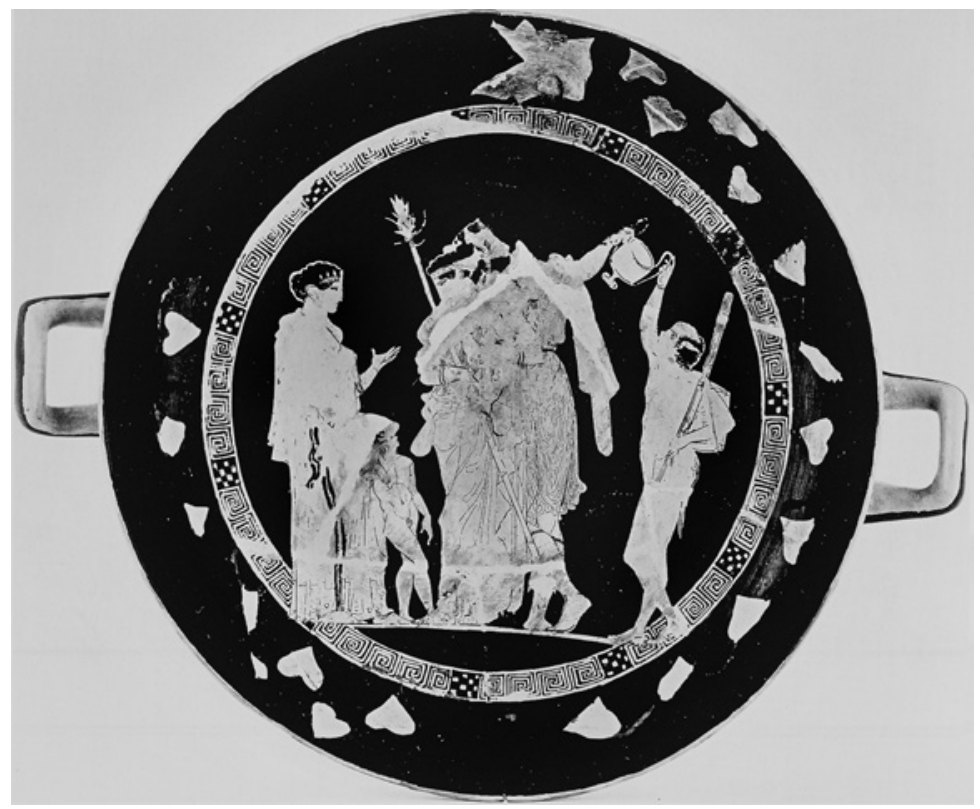

FIgURE 88 Cup, Kodros Painter, Würzburg, Martin von Wagner Museum der Universität H 4616, inside image (Avramidou 2011, pl. 21a).

raises his thyrsos as if it is a banner. An adult satyr playing the aulos leads the procession. ${ }^{134}$

The inside image of an extremely fine cup by the Kodros Painter from around 420 BC forms a worthy conclusion to this series (Figure 88). ${ }^{135}$ The Kodros Painter was the leading cup painter of the Parthenon period; he also created the beautiful scene with the divine symposium discussed earlier. ${ }^{136}$ In the center of this tondo a euphoric Dionysos leans heavily on his companion, who can be no other than Ariadne. He lifts a kantharos by its handle and seems on the verge of handing it to a boy-like satyr named Komos, who stands on the right with a torch in his left arm. Ariadne, however, looks towards the left. She is apparently engaged in conversation with a quietly standing woman wearing a sumptuous diadem and a heavy peplos. She is named as Pethon (possibly for Peitho). A young boy is leaning against her. He is called Pophs

\footnotetext{
134 New York 08.258.22: Addenda 354 (1249.12); BA 216948.

135 Würzburg H 4616 (491): Addenda 356 (1270.17); BA 217226; Shapiro 1993, 257, no. 118; PaulZinserling 1994, $41 \mathrm{f}$.

136 See above Chapter 5 , note 42 .
} 
(possibly Pothos), and looks up at Ariadne. ${ }^{137}$ The boy has neither the ear nor the tail of a satyr. Peitho und Pothos ('persuasion' and 'desire') are figures who belong to the circle of Aphrodite. The relationship between her circle and that of Dionysos, especially in the context of his love for Ariadne, is well known and supports the proposed interpretation of the inscriptions. However, as we have seen, in vase paintings gods and humans are sometimes brought together: Pethon could just as well be a prototypical Athenian woman, who presents her son (whose name could also be Posthon as on the calyx krater by the Villa Giulia Painter mentioned above) to the divine couple at some festive occasion.

In the eyes of François Lissarrague, who focused on the playful irony of satyr imagery, vase painters used the figure of the satyr child as a device to breach the boundaries of the polis and put into question the conventions of age and gender. His conclusion is plausible: “... le monde des satyres est un monde enfantin, un monde du jeu qui brouille sous forme plaisante l'image de l'identité masculine, virile et adulte du citoyen." ${ }^{138}$ This ties in with the fact that-as we have established for the first half of the century -in the minds of the vase painters and their original clients, satyrs perform the same acts, whether meritorious or dubious, as human men. ${ }^{139}$ The series presented here, which clearly stands out when one systematically investigates the whole iconography, has two other salient aspects. First, satyrs can be old, young or childlike, and therefore, like humans, move through various stages of the life cycle and experience the necessary Dionysiac changes. Secondly, satyrs make their appearance in contexts with obvious ritual connotations, and within those contexts their behavior is quite different from that shown in most thiasos images found on cups. Thus, they are not, with the father figure Silenus, the ageless beings of the mythical world of the past evoked in satyr plays, and neither can they only be found on the stage, separated from the audience. ${ }^{140}$ They also belong in the here and now of the original viewers of the vase imagery. They live in this world - as we had already established for the dancers and satyrs of the early 6th century-, a world permeated by the power of Dionsyos, where identities are in flux, where men appear as satyrs and satyrs as citizens. ${ }^{141}$ And satyrs can even be seen to play a ritually important role in all this.

\footnotetext{
137 Lezzi-Hafter 1985.

${ }_{13} 8$ Lissarrague 1998, 193-196; for satyrs of various ages see also Lissarrague 2013, 63-66.

139 See above Chapter 3, p. $5^{1}$ f. and p. 67 f.

140 Which is the gist of the argumentation of Hedreen 1992, $155 \mathrm{f}$.

141 Isler-Kerényi 2004a, 33.
} 


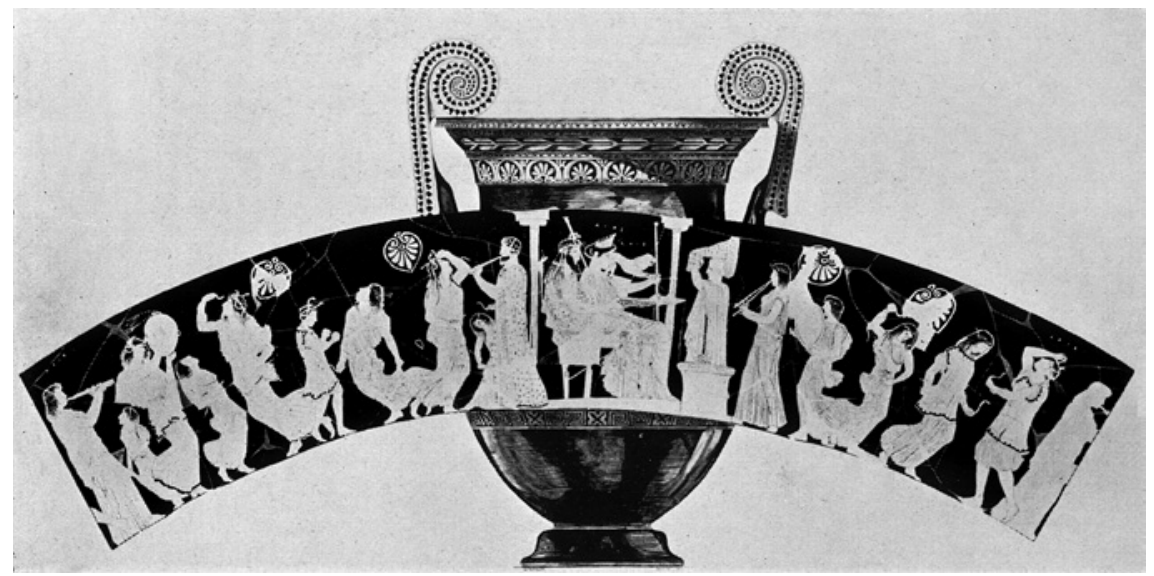

FIgURE 89 Volute krater, Curti Painter, Ferrara, Museo Archeologico Nazionale di Spina 2897, scroll showing both sides (Aurigemma 196o, pl. 22a).

\section{A Ritually Honored Etruscan Dionysos}

We repeatedly touched upon the issue of the reception of Greek vases and their imagery by an Eruscan clientele, for instance when we discussed the stamnoi with women ritually engaged before a temporary Dionysos idol or the Kodros cup with divine couples as symposiasts. ${ }^{142}$ The problem of the relationship between the Athenian vase painters and their Italian customers can be illuminated with the help of one of the most famous vases of the Classical period (Figure 89). ${ }^{143}$

The vase in question is a splendid volute krater, now attributed to the Curti Painter from the circle of Polygnotos and dated to shortly after 430 BC. ${ }^{144}$ It was found with other Attic red-figure vases, including a unique phallus vase as well as older Etruscan symposium utensils, in an extremely rich grave in the necropolis of Spina. ${ }^{145}$ Scholarship has so far neglected this important fact about the context of our vase. The questions of authorship, date, and especially the identification of the main figures have been approached as if this vase came from an Attic necropolis. The central element of the vase's iconography, a god enthroned, is quite problematic when considered in relation to the rest of the decoration. This may be divided into three parts. In the center of the

\footnotetext{
142 See above p. $130 \mathrm{f}$. and Chapter 5 , note 46.

143 Ferrara 2897: Addenda 322 (1052.25); BA 213655; LIMC III, Dionysos 869.

144 Halm-Tisserant 1984, 137 and $153 \mathrm{f}$.

145 A detailed interpretation, based on extensive iconographic research may be found in Isler-Kerényi 2002a and 2003.
} 
image a divine couple sits on a base between two pillars indicating a building. From the right approach, with measured pace, three female figures of various ages. The oldest woman, who leads the procession, carries on her head a liknon covered with a cloth; the second, younger one plays the aulos; the third one, a young girl, carries a tympanon. This obviously refers to some mystery cult. On the reverse a thiasos of twelve individuals, women and men, children and adults, dances ecstatically to the music of the aulos played by a musician who stands behind the seated gods, and by another, female, musician in the center of the image. The sound of the aulos is accompanied by the tympanon and cymbals held high by a boy under the left handle of the vase. ${ }^{146}$ Obviously, a very noisy affair. Some of the participants wear the ependytes, a colorfully embroidered short garment which makes an exotic impression. Most of them hold live snakes in their hands or have diadems with snakes on their heads. Such a diadem is also worn by the enthroned god. The Greeks associated this type of headdress with the Erinyes, the emissaries of the underworld.

On the one hand the god looks like Zeus, on the other like Hades. He cannot be Dionysos, because he holds a phiale instead of a kantharos, and a scepter instead of a thyrsos. Moreover, he does not wear an ivy wreath or a headband, but this remarkable snake diadem. His partner is represented supporting a lion on her lower arm. Because of this she has been identified as Kybele, a goddess from Asia Minor, and consequently her male partner as Sabazios-a god whose ecstatic cult had newly arrived in Athens towards the end of the $5^{\text {th }}$ century. ${ }^{147}$ However, women joining Dionysos in the battle against the giants or Dionysiac nymphs also carry lions in this manner. ${ }^{148}$ Seen from the perspective of Greek iconography, this god looks most like Hades, also because he sits inside a house. His partner would then be identified as Persephone.

But when considering the non-Greek clients, we come up against the problem that there is no iconography of the Etruscan Fufluns, that is, independent of that of the Greek Dionysos. From the Etruscan dedications on imported Greek ceramics already mentioned above one can conclude with certainty that at the time our krater was made, there was a mystery cult at Vulci for Dionysos assimilated with Fufluns. ${ }^{149}$ What we know of Etruscan religion in general allows us to state that this god had the same characteristics as the Greek Dionysos: the symbolism of grapes and wine, the symposium, ecstatic ritual,

146 Concerning the cymbals see above note 20.

147 In this way Halm-Tisserant 1984, 153.

148 Rausa 1991, 57; Carpenter 1997, 72.

149 See above note 34. The graffiti on a column krater found in Pyrgi are also very instructive, see Isler-Kerényi 2003, 45 . 
and, mediated by the figure of the satyr, male sexuality mostly as an expression of playful vitality. The latter aspect is represented amongst the Spina grave goods by a vase with a unique shape: a kind of tea mug with a sieve, decorated with erotic symposium scenes and with three large, plastically formed erect phalloi attached to its shoulder: a clear allusion to the hoped-for vitality. ${ }^{150}$ In addition, there is the relationship between Fufluns and the world of death, which was much stronger in the case of the Etruscans. Our krater makes this clear in the prominent place of the snakes in the ecstatic ritual. An Etruscan red-figure cup from Montepulciano, some three generations younger, shows Fufluns, slightly tipsy, in a symposium context. He is supported by a satyr, who wears the same snake diadem as the god on the Attic volute krater. ${ }^{151}$

If the enthroned god is supposed to be the Etruscan Fufluns instead of the Greek Dionysos, we must conclude that the volute krater-and, incidentally, the phallus pot-was made and decorated at the Kerameikos after the precise instructions of an Etruscan customer. Because the Curti Painter probably only had a very general knowledge of his client's cultural background, he combined disparate iconographical elements into this figure of a Hades-like Dionysos, venerated by exotic people of various ages, who was expected to bring succor to a wealthy citizen of Spina in his grave. Thus, the image of Dionysos was not set in stone, but could be adapted to the historical circumstances and culture of its beholders. This explains why this god of Athens and of Greece was enthusiastically adopted and venerated for centuries on the other side of the Adriatic. ${ }^{152}$ And it is not surprising that even in Athens itself, on the Parthenon, the god could be presented in an unfamiliar guise-which was immediately taken up by the vase painters, as we will see in the next chapter.

\footnotetext{
$150 \quad$ Isler-Kerényi 2002a, 79 f., 87 , fig. 7.

$15^{1}$ Isler-Kerényi 2002a, 81 and 87 , fig. 8. A similar snake diadem is worn by a female figure in a context that is unfortunately unknown on a fragment of an Attic column krater from Lokri, dated around 450-440 (Reggio Calabria, without inventory number): Giudice 2007, 114, no. 190.

$15^{2}$ Compare Bonfante 1993, whose ideas of Fufluns as a vegetation deity probably simplify matters too much. For the adoption of the iconography and cult of Dionysos in the Etruscan cities to the north of the Apennines, see Pizzirani 2009.
} 